University of Cincinnati College of Law

University of Cincinnati College of Law Scholarship and

Publications

Faculty Articles and Other Publications

College of Law Faculty Scholarship

2020

Ethnically Segmented Markets

Felix B. Chang

Follow this and additional works at: https://scholarship.law.uc.edu/fac_pubs

Part of the Antitrust and Trade Regulation Commons 


\section{ETHNICALLY SEGMENTED MARKETS}

FELIX B. CHANG*

Races often collide in segmented markets where buyers belong to one ethnic group while sellers belong to another. This Article examines one such market: the retail of wigs and hair extensions for African Americans, a multi-billion-dollar market controlled by Korean Americans. Although previous scholarship attributed the success of Korean American ventures to rotating credit and social capital, this Article ascribes their dominance in wigs and extensions to collusion and exclusion, tactics scrutinized under antitrust.

This Article is the first to synthesize the disparate treatment of ethnically segmented markets in law, sociology, and economics into a comprehensive framework. Its primary contribution is to forge the concept of ethnically segmented and misaligned ("ESM") markets, where buyers and sellers are ethnically distinct from one another.

ESM markets challenge entrenched paradigms in antitrust. In the wigs and extensions market, the endurance of Korean American retailers confounds conventional notions of market power, which is measured at the firm level. This market suggests that numerous in-group incumbents can compete intensely with one another but collaborate to stymie out-group insurgents.

\footnotetext{
* Professor and Co-Director, Corporate Law Center, University of Cincinnati College of Law. E-mail: felix.chang@uc.edu. I thank Danny Sokol for his insightful comments. Thanks, too, to Rebecca Haw Allensworth, Lynn Bai, Steve Calkins, Dale Collins, Harry First, Eleanor Fox, Hiba Hafiz, John Kirkwood, Doug Melamed, Barak Orbach, Sandra Sperino, Sean Sullivan, Joe Tomain, and Abe Wickelgren. This Article benefitted greatly from the antitrust workshop series at the University of Florida and the University of Cambridge.
} 


\section{Contents}

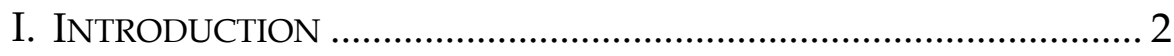

II. DEFINING ETHNICALLY SEGMENTED MARKETS ........................ 9

A. Contributions from Law .................................................... 9

1. Market division ............................................................. 9

2. Racial cartelization and exclusion................................ 11

3. Interplay between ethnicity and markets ...................... 12

B. Contributions from Sociology ............................................... 17

C. Contributions from Economics ............................................ 21

III. THE MARKET FOR WIGS AND HAIR EXTENSIONS...................... 25

A. Structural Tailwinds ........................................................... 26

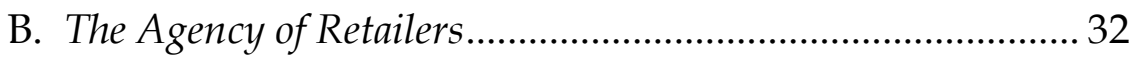

IV. MARKET POWER OF KOREAN AMERICAN RETAILERS............... 37

A. Oblique Measures of Market Power ..................................... 38

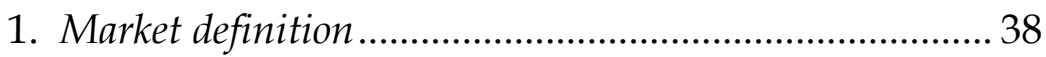

2. Market share calculation .............................................. 43

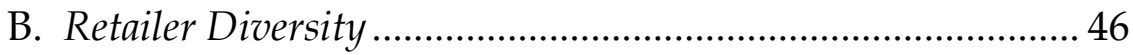

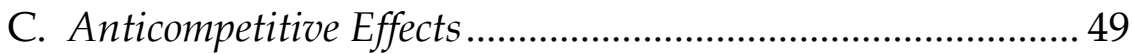

D. Facilitating Practices ........................................................... 54

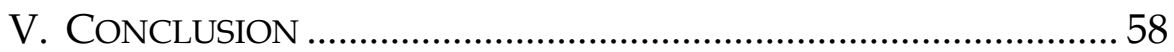




\section{INTRODUCTION}

Segmented markets are the product of markets dividing to serve groups with similar supply or demand preferences. ${ }^{1}$ In ethnically segmented markets, that division occurs due to ethnic or racial preferences. For instance, an all-white homeowners' association might exclude African Americans from a neighborhood to inflate home values, thereby segmenting its housing stock. ${ }^{2}$ More innocuously, grocery stores in a diverse city might track the segmented food preferences of its ethnic residents. ${ }^{3}$

The most puzzling-and disconcerting-ethnically segmented markets, however, are ones where consumers hail from one ethnic or racial group while sellers hail from another. Such markets present a conundrum: why are buyers and sellers ethnically distinct?

The piecemeal literature on ethnically segmented markets does not provide a satisfactory answer. In economics, the debate

1 Michael E. Porter, COMPetitive Strategy: TeChniques fOR ANAlyZing INDUSTRIES AND COMPETITORS 196-200 (1980).

2 See Daria Roithmayr, Racial Cartels, 16 MicH. J. RACE \& L. 45 (2010). Similarly, labor markets might be segment along the lines of occupation, geography, race, education, and immigration status. See Michael Reich et al., Dual Labor Markets: A Theory of Labor Market Segmentation, 63 AM. ECON. REV. 359 (1973); William T. Dickens \& Kevin Lang, Labor Market Segmentation Theory: Reconsidering the Evidence, in LABOR ECONOMICS: PROBLEMS IN ANALYZING LABOR MARKETS (William Darity, Jr. ed., 1993).

${ }^{3}$ See Ogenyi E. Omar et al., Food Shopping Behavior Among Ethnic and Non-Ethnic Communities in Britain, 10 J. FOOD PRODUCTS MARKETING 39 (2004). Some markets, such as ethnic foods, are more susceptible to consumer crossover than others, such as ethnic beauty products. With ethnic foods, debates of purity versus fusion replicate the economic discourse on market segmentation and integration while upping the cultural ante. See, e.g., Roxana Hadadi, Alison Roman, the Colonization of Spices, and the Exhausting Prevalence of Ethnic Erasure in Popular Food Culture, PAJIBA, May 9, 2020, https://www.pajiba.com/celebrities_are_better_than_you/alison-romanand-the-exhausting-prevalence-of-ethnic-erasure-in-popular-foodculture.php. 
has revolved around whether racial preferences are inefficient and, by extension, whether ethnically segmented markets should yield to market integration over time. ${ }^{4}$ Neither side convincingly explains why some ethnically segmented markets thrive as a misalignment of ethnically distinct buyers and sellers. ${ }^{5}$ After all, ethnically homogenous consumers should prefer to buy from coethnic producers. ${ }^{6}$

Legal scholars tend to examine ethnically segmented markets from the side of producers rather than consumers. Borrowing from antitrust theory, race and law scholars have framed the exclusion of peoples of color from housing and labor markets as a mechanism of racial cartels. ${ }^{7}$ In law and development circles, one camp of scholars has emphasized structural explanations for the dominance of ethnic groups in niche markets, typically against the backdrop of exclusion of all peoples of color from mainstream economies. ${ }^{8}$ By contrast, another other camp has fixated on the institutions, relationships, and private ordering peculiar to ethnic communities. ${ }^{9}$ In totality, however, legal scholars have not

4 See GARY BECKER, THE ECONOMICS OF DisCRIMINATION (2d ed. 1971).

${ }^{5}$ See Amanda Lea Robinson, Internal Borders: Ethnic-Based Market Segmentation in Malawi, 87 WORLD DEVELOPMENT 371 (2016).

6 In fact, silos of co-ethnic buyers and sellers mark societies that are characterized by high degrees of interethnic tension and economic fragmentation. See id.

7 See Roithmayr, supra note 2, at 51 (defining racial cartels as "groups in which members agree to artificially fix wages, property values, political power and other price-like analogues, by restricting supply, dividing up markets, or colluding to achieve other commercial conditions).

8 See, e.g., Eleanor Marie Lawrence Brown, The Blacks Who "Got Their Forty Acres and a Mule": A Theory of Black Weest Indian Migrant Asset Acquisition, 89 N.Y.U. L. REV. 27 (2014) (examining structural factors giving entrepreneurs from the West Indies a leg up, in comparison with other Black Americans).

9 See, e.g., Lan Cao, Looking at Communities and Markets, 74 NOTRE DAME L. REV. 841 (1999) (examining rotating credit associations in immigrant communities) [hereinafter Cao, Communities and Markets]; Amy L. Chua, Markets, Democracy, and Ethnicity: Toward a New Paradigm for Law and Development, 108 YALE L.J. 1 (1998) (correlating the success of some "market-dominant minorities" with 
articulated a comprehensive theory of markets that are both ethnically segmented and ethnically misaligned.

Sociology presents the most exhaustive treatment of these markets, though it, too, falls short in explaining the persistence of ethnic misalignment. Here the seminal work revolved around middleman minorities-sojourners such as Chinese, Jewish, Indian, and Lebanese merchants who mediate between majority and other minority groups. ${ }^{10}$ Over time, this framework morphed into ethnic entrepreneurs to cover non-itinerant groups. ${ }^{11}$ Nonetheless, it continued to miss the business tactics that enable in-group sellers to maintain dominance over out-group competitors. ${ }^{12}$

To unify the disparate approaches across law, economics, and sociology, this Article articulates a theory for the endurance of ethnically segmented markets where producers hail from one ethnicity while consumers hail from another-a concept this Article calls ethnically segmented and misaligned ("ESM")

their cultural dispositions); BARAK D. RICHMAN, STATELESS COMMERCE: THE Diamond Network AND the Persistence of Relational EXChange (2017) [hereinafter RICHMAN, STATELESS COMMERCE] (linking the success of certain ethnicities in the diamond industry with intraethnic exchanges and relationships); Teemu Ruskola, Conceptualizing Corporations and Kinship: Comparative Law and Development Theory in a Chinese Perspective, 52 STAN. L. REV. 1599 (2000) (tracing the development of Chinese corporate law to traditions of family and kinship).

10 See Hubert M. Blalock, TOWARD A THEORY OF MinORITy-Group RElations (1967); Edna Bonacich, A Theory of Middleman Minorities, 38 AM. Soc. REV. 583 (1973). See also Felix CHANG \& SUNNIE RUCKER-CHANG (EDS.), CHINESE Migrants in Russia, Central Asia AND Europe (2010); KHun-ENG KuAH \& Evelyn Hu DeHart (EDS.), VOlUnTARY ORGaNizATIONS IN THE CHINESE DIASPORA (2006).

${ }^{11}$ See IVAN LIGHT \& EDNA BONACICH, IMMIGRANT ENTREPRENEURS: KOREANS IN LOS ANGELES 1965-1982, 17 (1988) [hereinafter LIGHT \& BONACICH, IMMIGRANT ENTREPRENEURS]; See also Zulema Valdez, Beyond Ethnic Entrepreneurship: An Embedded Market Approach to Group Affiliation in American Enterprise, 15 RACE, GENDER \& CLASS 156 (2008).

12 But see In-Jin YoOn, ON My Own: Korean BusinesSES AND RaCE RELATIONS IN AMERICA (1997); In-Jin Yoon, The Growth of Korean Immigrant Entrepreneurship in Chicago, 18 ETHNIC \& RACIAL STUD. 315 (1995). 
markets. As its first step, the Article proffers a definition of ethnically segmented markets that encompasses all three disciplines. The Article's central contribution is to bring clarity to this concept, which has spanned multiple fields with no coherent framework.

Focusing on the retail of wigs and hair extensions to African Americans, which is dominated by Korean American firms, this Article illuminates that most peculiar of segmented marketswhere buyers and sellers are ethnically homogenous but misaligned. The size of the market for hair and extensions is estimated at $\$ 6$ billion. ${ }^{13}$ It is delineated along racial lines, with African American women comprising the largest segment. Due to a confluence of societal pressures and beauty standards, African American women are also steadfast consumers, ${ }^{14}$ so demand in the market is inelastic, which tends to support market power among producers. ${ }^{15}$

This Article argues that Korean American sellers (the market's main producers) maintain dominance not through structural or cultural advantages, but by collusion and exclusion. In mainstream economies, these strategies are employed by so many dominant firms that they have become the staple of antitrust cases. ${ }^{16}$ In ESM markets, however, coordination and exclusion assume a sociological dimension, with anticompetitive

13 Susan Adams, Long on Hair: The World's First Venture-Backed Human-HairExtension Company Wants To Be The Airbnb of Salons, FORBES, Sept. 27, 2019.

${ }^{14}$ See infra Section III.A.

${ }^{15}$ See infra Section IV.A.1.

16 See, e.g., Interstate Circuit, Inc. v. U.S., 306 U.S. 208 (1939) (parallel insertion of price maintenance clause into exhibition contracts by film distributors led to inference of collusion); American Column \& Lumber Co. v. U.S., 257 U.S. 377 (1921) (information exchange among hardwood manufacturers facilitated by trade association found to constitute price fixing); U.S. v. Foley, 598 F.2d 1323 (4th Cir. 1979) (communication among otherwise competing realtors facilitated their conspiracy to raise commission rates). 
effects reinforced by co-ethnic bonds. ${ }^{17}$ During the 1970s, it was a combination of economic forces, racial structures, and shifting beauty standards that initially propelled Korean-owned firms to power. ${ }^{18}$ This Article focuses on how Korean American retailers leveraged and maintained that power in the face of challenges by African American competitors. In these markets, retailers managed to band together intraethnically and fend off competition interracially, through tactics that can be conceptualized as antitrust offenses.

Antitrust is an apt springboard for analysis because African Americans often frame their relationship with Korean American retailers in anticompetitive terms. It is often asserted that Korean American firms exert a "monopoly" over, and have "monopolized," the Black beauty supply stores. ${ }^{19}$ Yet monopoly and monopolization have specific meanings that demand careful market power analysis. ${ }^{20}$ Working through the requisite steps infuses the literature on these buyer-seller interactions (and, accordingly, interethnic interactions) with rigor. Further, the interactions between African American buyers and Korean American sellers occur wholly outside the ambit of the state and therefore out of the purview of public law. That race relations

\footnotetext{
${ }^{17}$ This is not entirely straightforward. While Korean Americans can appeal to ethnic solidarity and utilize publications and associates to facilitate information exchange, intraethnic competition is intense. See LIGHT \& BONACICH, IMMIGRANT ENTREPRENEURS, supra note 11, at 193-93.

18 See Jason Petrulis, "A Country of Hair": A Global Story of South Korean Wigs, Korean American Entrepreneurs, African American Hairstyles, and Cold War Industrialization, 21 ENTERPRISE \& SOC. 1 (2020); Ku-Sup Chin et al., Immigrant Small Business and International Economic Linkage: A Case of the Korean Wig Business in Los Angeles, 1968-1977, 30 INT'L MigRATION ReV. 485 (1996). This history has entered popular imagination as well. See NICOLA YOON, THE SUN Is AlSO A STAR (2016).

${ }^{19}$ See Edward Tony Lloneau, How and Why Korean Owned Beauty Supply Stores Dominate in the Afro Community, LIQUID GOLD BLOG (2013) [archived at https://perma.cc/9D5U-BPNF].

${ }^{20}$ Herbert HovenKamp, Federal ANTITRUSt POlicy: The LAW OF COMPETITION AND ITS PRACTICE 92 (4th ed. 2011).
} 
often unfold as private transactions under private law is wellunderstood. ${ }^{21}$ Arguably, where transactions between races can be characterized as buyer-seller transactions, as in ESM markets, laws governing commerce are more appropriate than antidiscrimination laws as a point of entry.

Insights about ethnically segmented markets can push the boundaries of antitrust as well. The endurance of Korean American firms suggests that collusive and exclusionary schemes may be more stable than antitrust theory holds. Further, this market suggests that measuring market power at the firm level may not always be appropriate. While the literature on cartels has centered on a small number of large producers, ${ }^{22}$ coordination among a multitude of small firms in ESM markets is possible. ${ }^{23}$ This coheres with the axiom from sociology that an ethnic group withdraws into itself, strengthening co-ethnic bonds, when threatened by exogenous forces. ${ }^{24}$ This Article's second major contribution is therefore the discovery that in-group producers can coordinate against and exclude out-group competitors by utilizing ethnic bonds.

The remainder of the Article proceeds as follows: Section II synthesizes the treatment of ethnically segmented markets in law,

${ }^{21}$ Debate over the scope of public law to cover private actions stretches as far back as the Reconstruction Amendments. See HEATHER COX RiCHARDSON, WeST FROM APPOMATTOX: THE ReCONSTRUCTION OF AMERICA AFTER THE CIVIL WAR 204-05 (2007); George Rutherglen, State Action, Private Action, and the Thirteenth Amendment, 94 VA. L. REV. 1367, 1372 (2008) More recent discourse on the relevance of private law to interethnic relations includes Cao, Communities and Markets, supra note 9; RICHMAN, STATELESS COMMERCE, supra note 9.

22 The classic study is Reinhard Selten, A Simple Model of Imperfect Competition, Where 4 Are Few and 6 Are Many, 2 INT'L J. GAME TH. 141 (1973). See also Margaret C. Levenstein \& Valerie Y. Suslow, What Determines Cartel Success?, 44 J. ECON. LIT. 43 (2006); Andrew R. Dick, When Are Cartels Stable Contrcts?, 39 J.L. \& ECON. 241 (1996).

${ }^{23}$ National Society of Professional Engineers; BMI

24 Beleagurered merchants likely to withdraw into "distinctive cultural and organizational forms," thereby resisting integration. J.H. Turner \& Edna Bonacich, Toward a Composite Theory of Middleman Minorities, 7 ETHNICITY 144, 154 (1980). 
economics, and sociology to provide an edifice for the concept. Section III introduces the market for wigs and hair extensions as a template for ESM markets. Section IV works through the market power and facilitating practices of Korean American retailers. In doing so, it considers how this market pushes the boundaries of antitrust doctrine.

Before this Article proceeds further, an explanation of terminology is in order. First, this Article refers to "ethnically" segmented markets rather than "racially" segmented markets even though the latter could suffice for the retail of wigs and hair extensions to African Americans. African Americans, of course, are a racialized group,${ }^{25}$ while Korean Americans are an ethnicity within the Asian American racial group. ${ }^{26}$ Their misalignment in this market is both ethnic and racial. Nevertheless, the Article adopts "ethnic" for consistency with the sociological literature, which refers to ethnic entrepreneurs. ${ }^{27}$ This also attains a greater degree of precision regarding the producers (i.e., Korean Americans), rather than subsuming them in a larger racial category (i.e., Asian Americans, whose diverse constituents exhibit differing rates of entrepreneurship). This specificity is consistent with the antitrust notion that markets must be defined as narrowly as possible to accurately capture market power. ${ }^{28}$

${ }^{25}$ MiCHAEL OMI \& HOWARD WINANT, RACIAL FORMATION IN THE UNITED STATES (3rd ed., 2014). Recent scholarship, however, has come to view race as a power construct, rather than social construct. See, e.g., [prior work redacted for anonymity].

${ }^{26}$ For a thorough literature review of ethnicity, especially in the context of Asian Americans, see YEN LE EsPIRITU, ASIAN AMERICAN PANETHNICITY: BRIDGING INSTITUTIONS AND IDENTITIES 1-10 (1992).

27 See infra Section II.B.

28 See HovenKAMP, supra note 17, at 92 ("A relevant market is the smallest grouping of sales for which the elasticity of demand and supply are sufficiently low that a 'hypothetical monopolist' . . . could profitably reduce output and increase price..."). 


\section{Defining Ethnically Segmented MaRKets}

Existing treatment of ethnically segmented markets is, for lack of a better word, segmented along disciplines. Law, economics, and sociology have all tackled ethnically segmented markets, but through their narrow disciplinary confines. This Section assembles a definition of ethnically segmented markets from the disparate but complementary scholarship, with a view toward illuminating the markets at the crux of this Article. Ultimately, this Section arrives at the following definition of ethnically segmented and misaligned markets: buyers are ethnically homogenous and exhibit similar demand preferences but are served by producers who are themselves ethnically homogenous but also ethnically distinct from buyers.

\section{A. Contributions from Law}

\section{Market division}

Law's primary contribution to ethnically segmented markets is the insight from antitrust that markets divide. They divide naturally, as a result of consumer preferences, and artificially, as a result of coordination to boost and maintain market power. These divisions form the basis for market segmentation along the demarcations of ethnicity. Other legal concepts, such as racial cartels and the interplay between markets and ethnicity, build upon this intuition of segmentation.

Every market can be broken down into a product market and a geographic market. ${ }^{29}$ A product market might segment along price points, while a geographic market might splinter to reflect logistical challenges. For instance, the vast market for hotels is indisputably segmented along high-end and budget options, with a large and amorphous segment in the middle. In New York City, the Ritz Carlton or Waldorf Astoria might be interchangeable

${ }^{29} \mathrm{Id}$. at $\S \S 3.3,3.6$. 
with each other but not with budget motels. ${ }^{30}$ New York City may not even comprise one geographic market. Arguably, high-end hotels in Staten Island are not interchangeable with high-end hotels in Midtown Manhattan. ${ }^{31}$

With ethnically segmented markets, product markets are divided along ethnic lines. In a metropolis as large and diverse as Los Angeles, it would be foolhardy to define the grocery store market as all grocery stores in Los Angeles County. The product market is segmented along ethnic lines, catering to the tastes and preferences of the city's multitude of residents. ${ }^{32}$ This holds for even smaller slivers of the County. Thus, all grocery stores in the Mid-Wilshire area of Los Angeles cannot be lumped into one product market; given the area's diversity, grocery stores catering mostly to Chicano patrons might not be interchangeable with stores catering mostly to Ethiopian or Korean patrons. Further, considering the snarl of Los Angeles traffic, geographic markets should be drawn more compactly than in other cities. Thus, even if Asian grocery stores comprise a single product market, we might aptly define Asian grocery stores in Monterey Park and West Covina as separate geographic markets, even though both are located in the San Gabriel Valley. ${ }^{33}$ The 10 miles that separate

\footnotetext{
30 The two extremes are not interchangeable, meaning customers at either end are unlikely to cross over into the other segment. This is the hallmark of delineating a market, with boundaries drawn only around products that are not interchangeable or substitutable.

${ }^{31}$ Business and luxury travelers to Midtown Manhattan may be inclined to stay close to the center of financial activity or tourist attractions.

32 As an illustration of the aptness of the "ethnic" segmentation label, saying that grocery stores in Los Angeles are segmented along racial lines might even be too imprecise. The many ethnicities racialized as Hispanic, for instance, may diverge in culinary preferences. See Vanessa Fonseca, Nuevo Latino: Rebranding Latin American Cuisine, 8 CONSUMPTION, MARKETS AND CULTURE 95, 100-01 (2005).

${ }^{33}$ On the demographic fluctuations of Monterey Park, see Keith Aoki, Direct Democracy, Racial Group Agency, Local Government law, and Residential Racial Segregation: Some Reflections on Radical and Plural Democracy, 33 CAL. W. L. REV. 185 (1997).
} 
these two neighborhoods might be prohibitively far for a customer to drive to save, say, $10 \%$, on the cost of groceries. ${ }^{34}$

\section{Racial cartelization and exclusion}

Notably, market segmentation-including ethnic segmentation-can arise from more heavy-handed forces than product preferences or ease of transportation. Producers, rather than consumers, might divide markets to maintain market power-i.e., their ability to increase profits by reducing output and charging supracompetitive prices. ${ }^{35}$ Famously, a bar review course provider ceded the Georgia market to another provider in exchange for a covenant not to compete outside the state; thus, each monopolized a portion of the national market. ${ }^{36}$ In heterogenous product markets, firms might specialize in specific products so as to minimize overlap and attain market power. ${ }^{37}$

This nefarious strain of market segmentation informs what race and law scholars have coined as "racial cartels." 38 Just as several producers with small market shares can band together to divide a market among themselves, all-white associations can cartelize a market to raise economic, social, and racial status. ${ }^{39}$ Coordination foments power. More concretely, white unions went on strike to prevent employers from hiring Black and Chinese workers, thereby restricting the pool of available labor and boosting earning within that pool. ${ }^{40}$ White homeowners' associations persuaded homeowners to adopt racially restrictive

${ }^{34}$ For a discussion of the $10 \%$ figure, see HovENKAMP, supra note 17 , at 95-96.

35 United States v. E.I. du Pont de Nemours \& Co., 351 U.S. 377, 391 (1956).See also Thomas G. Krattenmaker et al., Monopoly Power and Market Power in Antitrust Law, 76 GEO. L.J. 241 (1987).

36 Palmer v. BRG of Georgia, Inc., 498 U.S. 46 (1990).

37 Kenneth M. Davidson, The Competitive Significance of Segmented Markets, 71 CALIF. L. REV. 445 (1983).

38 See Roithmayr, supra note 2.

39 See DARIA ROITHMAYR, REPRODUCING RACISM: HOW EVERYDAY CHOICES LOCK IN WHITE ADVANTAGE (2014).

40 [hafez] 
covenants that prevented home sales to African Americans, Asian Americans, and Latinos, thereby ensuring White ownership of homes and boosting home values. ${ }^{41}$ The Democratic Party purged Black members between the 1880s and the 1950s to lock-up political power. ${ }^{42}$ In each instance, Whites segmented the markets - for labor, for homes, and for political representationalong racial lines and inflated pricing and power through strategies of cartelization and exclusion.

From racial cartels, we discover that even small and discrete numbers can band together to concoct and execute exclusionary schemes. As we shall see, this pushes against the antitrust notion that cartels fare best when members are few and large and markets are concentrated. ${ }^{43}$ We can also begin to understand how some markets remain ethnically misaligned: through the hard work of cultivating oligopolies and exclusion.

\section{Interplay between ethnicities and markets}

Legal scholars have posited alternating theories for why certain markets are dominated by ethnically homogenous producers. One fixture among law and development scholars is Amy Chua, whose inquiries into "market-dominant ethnic minorities" began in the 1990s, soon after the Los Angeles riots and the fall of the Soviet Union. ${ }^{44}$ Professor Chua noted the similarities binding these minorities worldwide, who tend to

41 See Jacob S. Rugh \& Douglas S. Massey, Segregation in Post-Civil Rights America: Stalled Integration or End of the Segregated Century?, 11 DU BOIS REV.: SOC. SCI. RES. ON RACE 205 (2014); HARRIET B. NEUBURGER ET AL. NEIGHBORHOOD AND Life Chances: How Place MatTers in Modern AMERICA (2011); Roithmayr, supra note 2, at 52-53. See also Shelley v. Kraemer, 334 U.S. 1 (1948).

42 Roithmayr, supra note 2, at 65-70.

43 See Richard A. Posner, A Statistical Study of Antitrust Enforcement, 13 J. LAW \& ECON. 365 (1970); George A. Hay \& Daniel Kelley, An Empirical Survey of PriceFixing Conspiracies, 17 J. LAW \& ECON. 13 (1974); HOVENKAMP, supra note 17, at 159.

${ }^{44}$ See Chua, supra note 9; Amy CHUA, WORLd ON Fire: How EXPORTING FreE MARKET DEMOCRACY BREEDS ETHNIC HATRED AND GLOBAL INSTABILITY (2004). 
transact with "impoverished" and "disadvantaged" "indigenous" majorities. 45 She conjectured that economic and political liberalization fueled interethnic conflicts by strengthening the hand of the market-dominant minorities. ${ }^{46}$ While some of Professor Chua's subsequent writings provoked controversy, ${ }^{47}$ her work in this area remains influential.

Other scholars have examined the traits and communal practices within certain ethnic groups that fuel high rates of entrepreneurship. Here studies of the kye, or rotating credit systems in the Korean community, are emblematic. ${ }^{48}$ In rotating credit systems, members contribute money on a regular basis into a communal pot and take turns withdrawing from the pot. ${ }^{49}$ For law scholars, rotating credit signifies a broader pattern of informal arrangements held together by trust, ethnic solidarity, and decentralized information exchange-features endogenous to, and built up within, ethnic communities. ${ }^{50}$ To be sure, these

45 CHUA, supra note 41, at 6 and 7. Professor Chua's work has limited applicability to ethnically segmented and misaligned markets. In the U.S., buyers and sellers in these markets tend to be minority groups themselves; the dynamics are different and altogether fluid.

${ }^{46} \mathrm{Id}$. at 7 . On the use of competition law as a corrective to the influence of market-dominant minorities, see Eleanor M. Fox, Equality, Discrimination, and Competition Law: Lessons From and For South Africa and Indonesia, 41 HARV. INT'L L.J. 579 (2000).

47 Professor Chua subsequent books include AMY CHUA \& JED RUBENFELD, THE

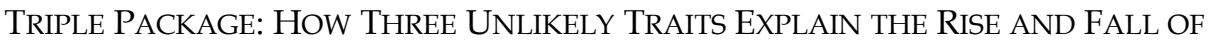
CULTURAL GROUPS IN AMERICA (2014), which would be criticized for suggesting that some minority groups are innately dominant and interethnic tension is inherent. See, e.g., Jennifer Lee \& Min Zhou, From Unassimilable to Exceptional: The Rise of Asian Americans and "Stereotype Promise", 16 NEW DIVERSITIES 7 (2014).

48 Other examples include the Chinese and Vietnamese "hui," the Japanese "tanamoshi," the Cambodian "thong thing," the Mexican "cundina," the Ethiopian "ekub," and West Indian "esusu." Cao, Communities and Markets, supra note 9 , at 848 .

49 These informal arrangements are often the primary source of funding for starting businesses.

50 See id. See also Lan Cao, The Diaspora of Ethnic Economies: Beyond the Pale?, 44 WM. \& MARY L. REV. 1521 (2003). 
scholars are cognizant of structural factors. Lan Cao, for instance, devotes plenty of discussion to why certain groups (e.g., Koreans, Chinese, and Mexicans) can amass capital while other cannot (e.g., African Americans). ${ }^{51}$ Hence, this literature might be characterized bottom-up studies of the endogenous and sociocultural factors that contribute to ethnic entrepreneurship. ${ }^{52}$

In a similar vein, Barak Richman has written on the control over the diamond industry exerted by ethnic groups who rely on private systems of contract enforcement. ${ }^{53}$ Jewish merchants in New York, for instance, owe their success to intraethnic institutions that enforce executory contracts and enable payment for diamonds on credit. ${ }^{54}$ Like the kye, these institutions function outside the auspices of any government, so Professor Richman calls them "stateless commerce." 55

Ethnic trading networks are also stateless in the sense that they cross national boundaries. The diamond trade is a transnational business controlled at certain junctures by specific ethnic groups, particularly Jewish merchants - just as wigs and hair extensions for African Americans are manufactured, distributed, and sold in a transnational chain where Koreans and Korean Americans predominate. Where the wigs and hair extensions market departs from the case studies of Professors Cao and Richman, however, is in its ethnic misalignment between producers and consumers. For the diamond markets to resemble this ESM market, customers would have to be ethnically homogenous peoples of color who are ethnically distinct from the merchants. Moreover, diamonds

${ }^{51}$ See Cao, supra note 9, at 879.

$52 \mathrm{Id}$. at 863.

53 See Barak D. Richman, Contracts and Cartels: Reconciling Competition and Development Policy, in COMPeTITION LAW AND Development (D. Daniel Sokol et al. eds., 2013); Barak D. Richman, How Community Institutions Create Economic Advantage: Jewish Diamond Merchants in New York, 31 LAW \& SOC. INQUIRY 383 (2006) [hereinafter Richman, Community Institutions]; RICHMAN, STATELESS COMMERCE supra note 9.

${ }^{54}$ Richman, Community Institutions, supra note 50, at 389.

55 RichMAN, STATELESS COMMERCE supra note 9, at xi. 
would have to be indispensable to conformity with mainstream aesthetic standards, 56 and co-ethnic sellers would have to be virtually nonexistent. ${ }^{57}$ Thus, while the bottom-up endogenous scholarship directs our attention to the institutional factors of Korean success (and those institutions certainly exist), ethnic misalignment of the wigs and hair extensions market requires that we consider two groups: purchasers and consumers.

At the other end of law and development scholarship are academics who look exclusively at structural explanations for the success of specific ethnic groups. ${ }^{58}$ Eleanor Brown, for example, positions her work on property rights as a complement to cultural approaches toward West Indians immigrants and their descendants, who exhibit much higher rates of entrepreneurship than other racialized Black Americans. ${ }^{59}$ Professor Brown relates the success of Black West Indians to their early exposure to property and contract rights as landholders on the islands. ${ }^{60}$ Land sales financed the emigration of West Indians, who upon arrival in the U.S. took advantage of their experiences to acquire land and build wealth - at substantially greater proportions than "native" African Americans. ${ }^{61}$ Interestingly, Caribbean families often became landlords to local African Americans. ${ }^{62}$

The relationship between Korean Americans and African Americans in the wigs and hair extensions market is even more visibly different because it is interracial. Of course, no discussion of Korean American-African American relations is complete

\footnotetext{
56 See infra notes 176-79 and accompanying discussion.

57 See infra note 198 and accompanying discussion.

58 Some scholars would place structural and cultural views in the same category, one emphasizing that certain institutions and cultural features determine behavior. At the other end is the agency or functionalist view, which emphasizes that individuals create institutions to serve their interests and needs. See Avner Greif, Institutions And the PATH tO THE Modern ECONOMY: LESSONS FROM MEDIEVAL TRADE 12-13 (2006).

${ }^{59}$ See Brown, supra note 8.

${ }^{60} \mathrm{Id}$. at $41-42$.

${ }^{61} \mathrm{Id}$. at 49 .

$62 \mathrm{Id}$. at 52 n.90.
} 
without mentioning that for all the relative difference in their stations, both are peoples of color excluded from participation in the mainstream economy. Therefore, their interactions have often been pushed to niches in urban landscapes where frictions are bound to arise. ${ }^{63}$ Smoldering for decades, these frictions exploded into riots in Los Angeles in 1992, when Korean American businesses were vandalized after the acquittal of the White police officers who beat Rodney King and the Korean American storeowner who shot Latasha Harlins. ${ }^{64}$ Law scholars with a structuralist bent were quick to underscore the similarities in systemic exclusion of both Asian Americans and African Americans, frequently with the blessing if not at the direction of the state. ${ }^{65}$ Asian American legal scholars, who were gaining prominence in the academy, called for the emergence of critical Asian American scholarship in the tradition of critical race theory. ${ }^{66}$ For all the shared legacy of discrimination and exclusion, however, when Korean American and African American interactions assume market dimensions, such as buyer-seller transactions, tensions can be exacerbated. ${ }^{67}$

63 See Kwang Chung Kim \& Shin Kim, The Multiracial Nature of Los Angeles Unrest in 1992, in KOREANS IN THE HOOD: CONFLICT WITH AFRICAN AMERICANS 17 (Kwang Chung Kim ed., 1999); Yoon, supra note 12, at 328.

${ }^{64}$ Kyeyoung Park, Use and Abuse of Race and Culture: Black-Korean Tension in America, in KOREANS IN THE HOOD: CONFLICT WITH AFRICAN AMERICANS 60 (Kwang Chung Kim ed., 1999); Melvin L. Oliver et al., Anatomy of a Rebellion: A Political-Economic Analysis, in READING RODNEY KING, READING URBAN UPRISING 117 (Robert Gooding-Williams, ed., 1993). See also Genaro Molina, How the Killing of Latasha Harlins Changed South L.A., L.A. TIMES, Mar. 18, 2016. ${ }^{6} 5$ See, e.g., Sumi K. Cho, Korean Americans vs. African Americans: Conflict and Construction, in READING RODNEY KING, READING URBAN UPRISING 196 (Robert Gooding-Williams, ed., 1993); Lisa C. Ikemoto, Traces of the Master Narrative in the Story of African American/Korean American Conflict: How We Constructed "Los Angeles", 66 S. CAL. L. REV. 1581 (1993); Reginald Leamon Robinson, "The Other Against Itself": Deconstructing the Violent Discourse between Korean and African Americans, 67 S. CAL. L. ReV. 15 (1993).

${ }^{66}$ See, e.g., Robert S. Chang, Toward an Asian American Legal Scholarship: Critical Race Theory, Post-Structuralism, and Narrative Space, 81 CALIF. L. Rev. 1241 (1993).

${ }^{67} \mathrm{Kim} \& \mathrm{Kim}$, supra note 60. 
From the structuralists, this Article extrapolates the lesson that ethnically misaligned buyers and sellers are pushed into close quarters by racial and macroeconomic forces. Departing from this starting point, however, the Article also scrutinizes the efforts of Korean American sellers to maintain the dominance that systemic forces conveyed them. To explain the persistence of ethnic misalignment, especially in the face of challenges to sellers by outgroup upstarts, the Article turns toward endogenous or bottomup perspectives to examine mechanisms adopted by in-group sellers. While this approach might be out of fashion in legal circles, given the popularity of systemic analyses, it is consistent with more recent sociological work, which has emphasized the agency of ethnic entrepreneurs. ${ }^{68}$

\section{B. Contributions from Sociology}

Sociology laid the foundation for ethnicity and entrepreneurship, providing basic definitions and theoretical frameworks. ${ }^{69}$ To this day, much of the innovative scholarship on ethnic markets resides in sociology. In 1967, Hubert Blalock devised the term middleman minority to describe minority entrepreneurs who mediate between dominant and subordinate groups. ${ }^{70}$ This concept became indelibly associated with Edna Bonacich, who posited that middlemen minorities succeed because they are sojourners or economic migrants intent on saving aggressively.71 Together with Ivan Light, Professor Bonacich conducted a series of ethnographic studies on Korean

68 See infra Section II.B.

${ }^{69}$ On basic definitions of, and the link between, ethnicity and entrepreneurship, for example, see Howard E. Aldrich \& Roger Waldinger, Ethnicity and Entrepreneurship, 16 ANNU. REV. SOCIOL. 111, 112 (1990) (defining "ethnic group" as membership in a group with a common origin and culture that is reinforced by social structures and "entrepreneurship" as combining resources in novel ways to create something of value).

${ }^{70}$ Hubert M. Blalock, TOWARD a THEORy OF MinORITY-Group Relations 79 (1967).

${ }^{71}$ See Bonacich, supra note 10. 
Americans, finding that this community exhibits high rates of entrepreneurship relative to other ethnic groups. ${ }^{72}$ Korean American firms compete by employing family members at low wages, thereby utilizing social networks to amass capital and control expenses. ${ }^{73}$ Their businesses also gravitate toward certain sectors (e.g., retail) and neighborhoods (e.g., impoverished or lower middle class). ${ }^{74}$

The middleman minority framework broadened into an ethnic or immigrant entrepreneur framework to encompass nonsojourning communities. ${ }^{75}$ Subsequent studies on Korean American entrepreneurs added to Light and Bonacich's observations, confirming that low-margin retail businesses in low-income neighborhoods function as the entry-point for most Korean Americans, who, after having saved enough, trade up for ventures in more prestigious industries and higher-income neighborhoods. ${ }^{76}$ These scholars also compiled a more sophisticated portrait of Korean American small businesses that relate their success back to two additional factors: (i) bilateral trade between the U.S. and Korea, which facilitated the import of manufactured goods from Korea and enabled Korean Americans to construct retail infrastructures for those goods; and (ii) a high degree of vertical integration of retail and import, which achieved efficiencies-but also fostered exclusion of out-group competitors. ${ }^{77}$

\footnotetext{
72 See LIGHT \& BONACICH, IMMIGRANT ENTREPRENEURS, supra note 11.

${ }^{73} \mathrm{Id}$. at 185-86; Yoon, supra note 12, at 328-29.

${ }^{74}$ LIGHT \& BONACICH, IMMIGRANT ENTREPRENEURS, supra note 11, at 179-84, 205-26.

${ }^{75} \mathrm{See} i \mathrm{i}$. at 18 . The sense of perpetual foreignness engendered by the immigrant framework would have been damaging to the very groups these sociologists studied. For a fuller discussion of the theories of ethnic economies, see IVAN LiGHT \& STEVEN J. GOLD, ETHNIC ECONOMIES 5-23 (2000).

${ }^{76}$ Jennifer Lee, Retail niche domination among African American, Jewish, and Korean entrepreneurs: Competition, coethnic advantage; and disadvantage, 42 AM. BEHAV. SCI. 1398 (1999).

77 Id. See also NANCy AbeLmanN \& JOHN Lie, Blue DreAms: KoREAN AMERICANS AND THE LOS ANGELES RIOTS 136 (1995).
} 
The paradigm shift to ethnic and immigrant entrepreneurs paved the way for ethnographies of other communities, often in fascinating contradistinction from co-racial groups. Scholars compared entrepreneurship rates and strategies of Cuban Americans to Mexican Americans, for instance, or Mexican Americans to African Americans. ${ }^{78}$ By unpacking the intersections of ethnicity with race, class, and gender, they have been able to distinguish ethnic communities prone to entrepreneurship from racialized minorities who, due to structural conditions or the absence of class and ethnic resources, could not replicate the conditions necessary for widespread business formation. ${ }^{79}$

Undertaking comparative analyses, sociologists ascertained that some ethnic groups thrived because they were able to integrate vertically and horizontally. ${ }^{80}$ Writing in 1982, Kenneth Wilson and Allen Martin theorized that ethnic communities utilizing in-group networks to organize in this way could replicate the advantages of dominant firms in the mainstream economy to squeeze out higher profits per unit of demand. ${ }^{81}$ As proof, they applied input-output econometric analyses to compare the production capacities of Cuban Americans and African Americans in Miami, finding that the former can source from in-group firms and retain capital within co-ethnic communities at far higher rates than the latter. ${ }^{82}$ Vertical integration has been observed between Korean American retailers and suppliers as well. ${ }^{83}$

78 See Zulema Valdez, The New EnTRepreneurs: How Race, Class, AND GENDER SHAPE AMERICAN ENTERPRISE 26 (2011).

${ }^{79}$ For a concise literature review, see Valdez, supra note 11, at 158.

80 See Kenneth L. Wilson \& W. Allen Martin, Ethnic Enclaves: A Comparison of the Cuban and Black Economies in Miami, 88 AM. J. SociOL. 135 (1982).

${ }^{81} \mathrm{Id}$. at 138.

82 Id. at $143-47$.

${ }^{83}$ See Yoon, supra note 12, at 331: 
As we assemble the literature on ethnically segmented markets, it is important to be mindful of sociology. Sociology keeps legal scholars "honest" about ethnicity, so to speak, by helping us stay attuned to the dynamism of racial and ethnic formation. ${ }^{84}$ Recognizing that race and ethnicity are constructs whose boundaries are fluid, we understand that the interethnic conflict in ESM markets is not inevitable. Indeed, the static representation of ethnicity-and therefore the inevitability of ethnic conflict-was one of the many criticisms of Professor Chua's writings. 85 Generations pass and their descendants acculturate; whatever the values or inclinations of first-generation immigrant entrepreneurs, their children may feel differently about the communities where they do business. ${ }^{86}$

In return, there is much that antitrust can teach sociologists as well. The literature on vertical integration in ethnic economies is

The vertical integration between Korean retailers and suppliers is another strong feature of Korean immigrant businesses .... Korean retailers say that they receive some benefits or special services from Korean suppliers. For example, extended credit terms, lower prices and easy access to information are the main benefits gained from having Korean suppliers. Since Korean suppliers dominate general merchandise, clothing, footwear, and wig trades, Korean retailers can get early information about which items have recently arrived and which ones are "hot."

${ }^{84}$ On the process of racial formation, see OMI \& WINANT, supra note 22.

85 See Edmund Terrence Gomez, Inter-ethnic Relations, Business and Identity: The Chinese in Britain and Malaysia, in THE STATE, DEVELOPMENT AND IDENTITY IN Multi-ETHNiC SOCIETIES: ETHNICITY, EQUiTY AND THE NATION 32 (Nicholas Tarling \& Edmund Terrence Gomez eds., 2008) ("[Chua's] perspective tends to homogenize ethnic communities and to essentialize their pattern of enterprise development"); Miles, Chinese Diasporas, pp 256-257

86 See Elaine H. Kim, Home is Where the Han Is: A Korean American Perspective on the Los Angeles Upheavals, in READING RODNEY KING, READING URBAN UPRISING 215 (Robert Gooding-Williams, ed., 1993). Concomitantly, we also see that traumatic episodes such as the LA riots can accentuate ethnic solidarity. Rose M. Kim, Violence and Trauma as Constitutive Elements in Korean American Racial Identity Formation: The 1992 L.A. Riots/Insurrection/Saigu, 11 ETHNIC \& RACIAL STUD. 1999 (2011). 
now nearly half a century old. ${ }^{87}$ Some of it treats horizontal coordination and vertical integration equivalently, ${ }^{88}$ as tantamount to a monopoly. ${ }^{89}$ These are fighting words in antitrust; there, the doctrine has developed frameworks for thinking through when monopolies ensue, what monopolization is, and when coordination and integration should be condemned.

\section{Contributions from Economics}

Economics is fundamental to our understanding of markets, and economic principles heavily influence antitrust. For our purposes, three lines of economic scholarship are informative. First, there has been a longstanding debate about the relevance of antidiscrimination laws - from an economics perspective. Among the earliest, and certainly the loudest, volleys fired on this point came from the Chicago economist Gary Becker, who posited that racial discrimination is inefficient because it artificially steers transactions toward in-group members rather than permitting out-group but more efficient alternatives. ${ }^{90}$ For instance, White employers with a "taste for discrimination" might hire only White workers even though Black workers might be more productive and demand lower wages. ${ }^{91}$ Over time, as his theory goes, the markets would correct the distortions of discrimination by, with nondiscriminators driving discriminators out of business. ${ }^{92}$ In the

87 A similar strain is the "ethnic cartel" model. For a discussion, see RICHMAN, STATELESS COMMERCE supra note 9, at 107-08.

88 See Wilson \& Martin, supra note 77, at 137.

89 See LigHT \& GOLD, supra note 76, at 20-21 ("Korean business owners monopolized the wig business before federal prosecutors brought suit under the Sherman Anti-Trust Act. While they enjoyed their monopoly, Korean business owners excluded non-Koreans from the wig industry, and raised prices of wigs to consumers.").

${ }^{90}$ See BECKER, supra note 4.

${ }^{91} \mathrm{Id}$. at $19-21$.

92 Id. at 43-45. See also RichARD A. POSNER, ECONOMIC ANALYSIS OF LAW § 21.1 (1972). 
above example, White employers would eventually gravitate toward Black workers, forcing a stabilization of wages between White and Black workers. With the markets' self-correction, antidiscrimination laws were unnecessary. ${ }^{93}$

Becker's thesis came at the height of U.S. antidiscrimination laws and ushered in a conservative backlash rooted in shaky microeconomic theory. The thesis has been thoroughly qualified, if not utterly discredited, ${ }^{94}$ though Professor Becker's other writings have influenced scholarship of ethnic entrepreneurs. ${ }^{95}$

For our purposes, and as our second line of scholarship to examine, it is the related discourse on the durability of market segmentation that is more relevant. The lesson from the early microeconomics-infused lens on race is that segregation is inefficient. ${ }^{96}$ As time takes its course, transactions should proceed toward the equilibrium of efficiency. This hypothesis applies to various settings, with the common theme that markets and communities should move toward integration. Thus, across vastly different industries, market segmentation is viewed as an aberration. Financial markets are inefficient where producers are siloed, fostering redundancy in market infrastructures. ${ }^{97}$ Labor unions are interpreted as artificial in addition to unjust where

${ }^{93}$ See BECKER, supra note 4 , at 45.

${ }_{94}$ See, e.g., Robert E. Suggs, Poisoning the Well: Law $\mathcal{E}$ Economics and Racial Inequality, 57 HASTINGS L.J. 255 (2005).

${ }^{95}$ See, e.g., Richman, Community Institutions, supra note 50, at 387-88 (accounting for the possibility that that Jewish institutions developed and internalized knowledge that allowed Jewish merchants to flourish in the diamond trade, in accordance with Becker's theory of human capital suggests); Cao, Communities and Markets, supra note 9, at 865 n.84 (incorporating Becker's work on norms into an understanding of community norms surrounding informal contracts).

96 Becker himself posited that tastes for discrimination might grow large enough to foster segregation and pre-empt intercommunal trade, to the detriment of each isolated community's welfare. See BECKER, supra note 4 , at 22-23.

97 See Mike Reece, Competition or Consolidation?: The Outlook for Interoperability Among European CCPs, THOUGHT (J.P. Morgan), May 1, 2012 (comparing the siloed nature of financial market infrastructures in Europe versus the U.S.). 
peoples of color are excluded. ${ }^{98}$ And trade barriers, a form of geographic market segregation, are construed as artificial distortions of price, which should otherwise trend toward uniformity. ${ }^{99}$

In diverse societies, then, the persistence of ethnically segmented markets might be attributed to unnatural forces such as interethnic suspicion. In Malawi, for example, the political scientist Amanda Lea Robinson has analyzed the spatial distribution of the country's numerous ethnic groups and concluded that ethnic market segmentation is partially the result of intraethnic trust. ${ }^{100}$ To minimize the risks of informal commerce, farmers and traders opt to transact only with in-group counterparties. ${ }^{101}$

Nonetheless, ethnic groups can come to so dominate an economic niche that consumers cannot turn to coethnic suppliers. For an explanation, and as our third line of scholarship to examine, some economists have turned to institutions peculiar to those ethnicities. New institutional economics ("NIE") defines institutions as "written and unwritten rules, norms and constraints that humans devise to reduce uncertainty and control their environment." 102 Broadly construed, institutions cover written rules and agreements governing private relations, constitutions and laws governing society, and unwritten codes of conduct. ${ }^{103}$ In his seminal book on institutions, for instance, Avner Greif traces Western dominance to the development of institutions during the medieval era that fostered growth. ${ }^{104}$ Most

98 Roithmayr, supra note 2, at 51.

99 See Robinson, supra note 5 (discussing the Law of One Price, which hypothesizes that each product should have one price globally and where disparities arise, they are due to trade frictions).

$100 \mathrm{Id}$.

$101 \mathrm{Id}$.

102 Claud Menard \& Mary M. Shirley, Introduction, in HANDBOOK OF NEW INSTITUTIONAL ECONOMICS (Claud Menard \& Mary M. Shirley eds., 2008).

${ }_{103} \mathrm{Id}$.

104 See AVNer GREIF, INSTITUTIONS AND the PATH TO THE MODERn ECONOMY: LESSONS FROM MEDIEVAL TRADE (2006). 
prominently, it was the rise of corporations such as guilds, fraternities, and professional organizations-institutions institution centered neither on state nor kin but on self-interest and self-governance - that propelled Europe's growth. ${ }^{105}$

Given its emphasis on hard and soft law as institutions fundamental to economic success, NIE has provided the foundations for law scholars' studies of ethnic economies. ${ }^{106}$ As we shall see, institutions spurred the ascension of Korean merchants' in the African American wigs and hair extensions market. However, we will also move beyond intraethnic and communal factors to evaluate Korean American strategies for keeping competitors at bay. Because the market for the sale of wigs and hair extensions to African Americans is ethnically misaligned between consumers and producers, we must consider the part that producers played in maintaining their edge over outgroup competitors-specifically, African American retailers, whom consumers would likely have preferred.

Altogether, prior writings from law, sociology, and economics point to the following quandary for ESM markets: given the dynamism of racial and ethnic formation as well as the transience and inefficiency of market segmentation, why are some ethnically segmented markets perpetually misaligned? Existing work (e.g., by NIE scholars) provides partial answers. But to fully explicate this quandary, the remainder of the Article focuses on one of the country's most iconic but misunderstood ESM markets.

105 Id. See also Avner Greif, Family Structure, Institutions, and Growth: The Origins and Implications of Western Corporations, 96 AEA PAPERS \& PROC. 308 (2006). 106 See, e.g., RiCHMAN, STATELESS COMMERCE supra at 91, 169. 


\section{THE Market fOR AfRICAN WIGS AND HAIR EXTENSIONS}

Wigs and hair extensions manufactured for African American consumption comprise an ethnically segmented product market. African American hair is unique in texture and remarkably versatile, capable of being molded into different styles as an expression of personal style. ${ }^{107}$ Yet with this versatility comes fragility; excessive styling weakens the hair shaft so consumers often cannot use products designed for other hair types. ${ }^{108}$ Products catering to African American hair, therefore, are generally not substitutable by hair products for other ethnic groups. ${ }^{109}$

Unlike many other consumer products, however, wigs and hair extensions are sold in an ethnically misaligned market because retailers are predominantly firms owned by Korean Americans. In the U.S., this is one of the most enduring markets where buyers and sellers are ethnically misaligned.

107 Ingrid E. Roseborough \& Amy J. McMichael, Hair Care Practices in AfricanAmerican Patients, 28 SEMIN CuTAN. Med. SuRG. 103, (2009):

The unique properties of hair of African origin are conducive to the expression of personal style.T he curved, ellipticallyshaped hair shaft lends itself to mouldable styles that retain their form and texture. When heat or chemical agents are applied to African hair, thes trands temporarily or permanently release their intrinsic coil properties and can be fashioned in innumerable ways. This immense diversity of options for hair care is not without drawbacks. African hair is innately fragile. The inappropriate use of styling aids may weaken the hair shaft and lead to breakage, scalp inflammation, and potentially permanent hair loss.

$108 \mathrm{Id}$.

${ }^{109}$ For example, African American hair generally requires more conditioning to prevent dryness. For wigs and hair extensions, styles with tighter curl pattern will generally be used more by African American consumers than white or Asian consumers. 
Equally enduring is the interethnic tension that typifies consumer-producer interactions. (By "producers," this Article refers generally to retailers of wigs and hair extensions for African Americans.) Understandably, the fact that Korean Americans dominate the sale of beauty products manufactured for African Americans has been the source of consumer ire for decades. Among other criticisms, African Americans routinely level generalizations that these markets are concentrated and Koreans have monopolized them. ${ }^{110}$ Pervasive as these charges are, the stranger feature is that they have been repeated by scholarsoften the scholars who built up the middleman minority literature-without working through the prerequisites of monopoly and monopolization. ${ }^{111}$

This Section analyzes the retail of wigs and hair extensions to African American as a paradigm of ESM markets. It begins with the structural dynamics that propelled Korean American firms into the markets. Then it discusses the tactics that these firms utilize to sustain their control. Finally, with a view toward infusing the discourse with greater methodological rigor, this Section dissects the market power of Korean American retailers.

\section{A. Structural Tailwinds}

Today's Korean American hair retailers owe their start to macroeconomic changes at the domestic and international levels in the late 1960s. Half a century ago, when South Korean

\footnotetext{
110 See, e.g., Emma Sapong, Roots of Tension: Race, Hair, Competition and Black Beauty Stores, MinNesota Public RAdiO News, Apr. 25, 2017, https://www.mprnews.org/story/2017/04/25/black-beauty-shops-koreansuppliers-roots-of-tension-mn [https://perma.cc/EG7Y-DU7X]; GOOD HAIR (HBO Films 2009); BLACK HAIR (2006), available at https://www.youtube.com/watch?v=p96aaTSdrAE; Lloneau, supra note 16. See also BLACK OWNED HAIR CHALLENGE, https://www.blackownedhaircarechallenge.com/ (last accessed July 30, 2020).

111 See, e.g., LIGHT \& GOLD, supra note 76, at 20-21.
} 
underwent its rapid economic development, ${ }^{112}$ wigs became one of the country's major exports. ${ }^{113}$ Hair collectors traveled the countryside of South Korea, offering cash to or even bartering with women and girls in exchange for their hair. ${ }^{114}$ Shorn hair was bundled and sold to wholesalers, who then resold it to wig factories. Wig manufacturing is labor-intensive: hair must be combed and sorted for length; if the hair is natural, it must also be disinfected, washed, curled, and dyed; finally, hair is then sewn onto a cloth netting. ${ }^{115}$ Yet wage imbalances allowed wigs to be made in South Korea, imported into the U.S., and then sold at large markups. 116

By a twist of history, South Korean wig exports were greased by anti-Communist policy during the Cold War. In the early 1960s, at the height of a hairpiece craze in the U.S., European supplies of hair ran low, so U.S. manufacturers began to source hair from China. ${ }^{117}$ In 1965, however, the U.S. Treasury Department suddenly banned the import of "Asiatic" hair, but hair was allowed through the embargo if it could be traced to a non-Communist source. ${ }^{118}$ This move boosted the South Korean wig industry while undercutting its Asian competitors.

Initially, South Korean wig imports were fueled by an explosion in consumer demand, which grew 50-fold from 1960 to 1969.119 At that time, the market was expanding so quickly that

112 See Gregg BraZinsky, NAtion Building in SOUTH Korea: Koreans, AMERICANS, AND THE MAKING OF A DEMOCRACY (2007).

113 LIGHT \& BONACICH, IMMIGRANT ENTREPRENEURS, supra note 11, at 266 ("Korea exported 70 percent of the world's human-hair wigs.").

114 Petrulis, supra note 15, at 8. See also How Wigs Tell the Story of Modern South Korea, ECONOMIST, Jul. 27, 2017.

115 Loretta Hall, Wig, How Products Are Made, http://www.madehow.com/Volume-3/Wig.html (last accessed July 30, 2020).

116 See LigHT \& BONACICH, IMMIGRANT ENTREPRENEURS, supra note 11, at 27-37; Chin et al., supra note 15, at 494 .

117 Petrulis, supra note 15 , at 13.

118 Id. at $14-15$.

119 See Leslie Gourse, What a Change of Hair Can Do, N.Y. TIMES, Nov. 16, 1969. 
U.S. firms set up subsidiaries and stepped up sourcing. ${ }^{120}$ Hong Kong and South Korean businesses also rushed in. What distinguished the Korean-operated supply chain from its U.S. and Hong Kong counterparts, however, was its reliance on an extensive network of large manufacturers, small distributors, and a government-backed bank that stretched from South Korea to the U.S. ${ }^{121}$ State support was critical. Funded by the South Korean government, the Korean Exchange Bank established a branch in Los Angeles to lend to Korean American-owned firms, many of them situated in the wig industry. ${ }^{122}$ The bank even encouraging these firms to borrow, thereby swelling the number of wig trading companies in the early 1970s. ${ }^{123}$

Korean-owned businesses in the U.S. built up a network of wig wholesalers and retailers, all relying on each other. Koreanlanguage newspapers circulating in the U.S. advertised the enterprises of Korean immigrants, which helped connect immigrants; Korean importers also recruited Korean immigrants as distributors. ${ }^{124}$ Newcomers to the wig business could navigate both financing and sourcing solely within the transnational Korean community. Hence, social networks linked the disparate players in the wig market.

The late 1960s and 1970s also coincided with shifting beauty standards. This was the era of full beards and long hair, reflecting an ethos of rebellion. For those consumers unable to naturally look the part, hairpieces provided a substitute-though a costly one. At the time, wigs were sourced from human hair, and Italian

\footnotetext{
${ }^{120}$ Chin et al., supra note 15, at 494 .

121 Id. at $499-501$.

122 Id. at 498 .

123 Id. at 499 .

124 Yoon, supra note 12, at 322 ("Korean manufacturers sent their sales representatives to black areas to open retail stores. Korean wig-importers actively recruited Korean immigrants as retailers and peddlers in black areas to expand their businesses. They even supplied wigs to Korean retailers on credit, so that Korean immigrants could start their own wig businesses with very little initial capital.").
} 
hair was considered topshelf, with "Oriental" hair a distant second. ${ }^{125}$ Mixing animal hair was already in practice to concoct even cheaper alternatives. ${ }^{126}$ However, it was the invention of Kanekalon by the Japanese conglomerate Kanekan in 1965 that proved disruptive. ${ }^{127}$

Possibly intended as a wool substitute, ${ }^{128}$ and modeled on Union Carbide's fibers for fake fur and doll hair, ${ }^{129}$ Kanekalon was a synthetic thread that became an inexpensive substitute for human hair. Korean wig manufacturers acquired the exclusive right to use the thread and incorporated it into their products. ${ }^{130}$ Along with the technical breakthrough of stretch wigs, or hair attached onto elastic caps, ${ }^{131}$ Kanekalon helped South Korea transform from an source of human hair to a manufacturer of wigs. ${ }^{132}$ By the mid-1970s, wigs had become South Korea's third

${ }^{125}$ A direct, if lengthy, quote from a chronicler of the time is illuminating on multiple levels:

[T]raditional pacesetters are the hairpieces from Europe, led by soft, shiny, olive-oil-nurtured Italian hair. It is far and away the most expensive, with falls starting as high as $\$ 300$ and full wigs going for as much as $\$ 1,000 \ldots$. . Spanish hair has been under something of a cloud since the days when gypsies were accused of kidnapping long-haired children, and returning them shortn .... Oriental hair is in general coarser than the European variety, and cheaper. A hairpiece of Oriental hair costs roughly a third of the price of a comparable European piece. Gourse, supra note 112, at 67-69.

126 See id. at 69.

127 See About Kaneka, Kaneka, https://www.kaneka.co.jp/en/corporate/chronicle/ (click on "1960 ").

128 Brooklyn White, How Black Women Fueled Kanekalon Hair's Enduring Impact on Pop Culture, StyleCaster, https://stylecaster.com/beauty/kanekalon-hairhistory/.

${ }^{129}$ Gourse, supra note 112, at 69.

130 Yoon, supra note 12, at 111 .

131 Gourse, supra note 112, at 69.

132 Chin et al., supra note 15, at 495. 
largest export. ${ }^{133}$ For consumer standpoint, Kanekalon provided a low-cost alternative to natural wigs, putting conformity to fashion trends within nearly universal reach. ${ }^{134}$

For African American women, who comprise a very specific market segment, the mid-1970s marked a shift from the afros that had defined the Civil Rights era to longer, straighter hair. ${ }^{135}$ This was reflected in the cultural icons of the day, including Diana Ross and Donna Summer. ${ }^{136}$ Of course, hair is an individual's expression of identity, so we must not overgeneralize. We do know, however, that emerging sources of natural and synthetic hair from Asia brought down the prices of wigs, enabling more consumers to look the era's part. At a time when relaxers and straight hair were coming back into style, synthetic wigs allowed African American women to quickly change up hairstyles. ${ }^{137}$

Synthetic wigs therefore ushered in throwaway fashion for hair - a boon to Korean American wig retailers, who in the mid1970s were suffering from the deflation of their products, an economic recession, weakening consumer demand, and intensifying intraethnic competition. ${ }^{138}$ Henceforth, these retailers would have to do volume business to make up for diminishing margins. Yet were it not for African American women, South Korean manufacturers and Korean American retailers would likely not have survived. In less than half a decade, consumption

$133 \mathrm{Id}$. at 496.

134 See Gourse, supra note 112, at 69 (synthetic wigs cost $\$ 25$, as opposed to the $\$ 300$ price tag for wigs from natural hair).

135 Previously, the late 1960s and early 1970s was the "golden era of wigs." Yoon, supra note 12, at 323.

${ }^{136}$ For annals of their hair evolution, see Nikki Brown, Diana Ross' Unmatched Hair Journey Through The Years, ESSENCE, Feb. 8, 2017, https://www.essence.com/celebrity/diana-ross-hair-journey/; Nicole Marie Melton, Hairstyle File: Donna Summer's Iconic Tresses, ESSENCE, May 18, 2012, https://www.essence.com/hair/hairstyle-file-donna-summers-tresstransformation/.

137 See AYANA BYRD \& LORI THARPS, HAIR STORY: UNTANGLING THE ROOTS OF BLACK HAIR IN AMERICA 70-71 (2001).

138 YOON, supra note 12, at 112-13. 
of wigs in the U.S. contracted by nearly 40 percent, to a "core" constituent of African Americans. ${ }^{139}$ This group comprised a lucrative and dependable segment, and because of the inroads Korean Americans had already made into the market, they would not be displaced.

Other seismic but fortuitous trends allowed Korean American firms to consolidate control over the wigs and hair extensions markets. As whites fled American cities, Korean American retailers set up convenient stores, liquor stores, and hair care businesses, taking advantage of cheap rents to open storefronts. ${ }^{140}$ Brick and mortar establishments gave owners direct access to the consumers who would form their base, so that when styles shifted, firms could quickly adapt by switching to newer products. In this way, the early foray of Korean American retailers conveyed this set of producers a first mover advantage which made them difficult to unseat. ${ }^{141}$ Their entry into the community also signified the demise of door-to-door retailing of the 1930s, the mainstay of black retailers who sold black-made beauty products directly to black consumers. ${ }^{142}$ In their place stood the brick and mortar store, where Korean American retailers sold beauty supplies manufactured in Korea to black consumers. ${ }^{143}$

Of all the structural tailwinds enjoyed by Korean American retailers, however, it is their comparative advantage over African American competitors that has kept them ahead. In many respects, a comparison of these two communities is a study in contrasts. Where one group of producers has access to capital, whether through rotating communal credit or state-backed import-export banks, the other is shut out of mortgages, let alone

139 Petrulis, supra note 15 , at 5.

140 See Sapong, supra note 107.

141 See id.

142 See BYRD \& THARPS, supra note 130 , at 32,79

$143 \mathrm{Id}$. at 34 . 
business credit. ${ }^{144}$ Where one group enjoys the patronage of a sovereign government that during the 1960s was still a quasideveloping country but threw its entire weight behind its ethnic compatriots, the other group has faced the systematic exclusion, marginalization, and persecution by its own state, a world superpower. No study of this ethnically misaligned market would be complete without reference to the disparity in buyer and seller economic power, and no study of that economic power would be complete without mention of the headwinds African American businesses perpetually face.

Nonetheless, Korean American dominance cannot be entirely chalked up to structural or institutional advantages. The innovation and success of African American entrepreneurs such as Madam C.J. Walker, who pioneered hair straightening products and a direct retailing strategy, shows that African Americans can break through. ${ }^{145}$ Nor is Walker an anomaly; numerous other Black-owned hair care businesses have flourished despite the headwinds. ${ }^{146}$ For Korean American retailers, then, we must also look at the role that this group played in fanning those headwinds.

\section{B. The Agency of Retailers}

Structural trends may convey one set of producers an advantage over others, but the advantages are ephemeral. Structures shift, and advantages dissipate. This is especially the case when producers and consumers are both communities of color; the slight, relative advantages conveyed to each group

${ }^{144}$ Cf. Yoon, supra note 12, at 494, with RICHARD ROTHSTEIN, THE COLOR OF LAW: A ForGotTEN History OF HOW OUR GOVERNMENT SEGREGATED AMERICA 9-10 (2017).

145 BYRD \& THARPS, supra note 130 , at 35-36, 78-81. Walker was the first Black self-made female millionaire. $I d$. at 183.

146 See Black-Owned Brands, BLACK OWNED HAIR CHALLENGE, https:// www.blackownedhaircarechallenge.com/black-owned-brands/ (last accessed July 30, 2020). 
fades quickly, and relations between ethnically distinct producers and consumers are ever fluid. ${ }^{147}$ In other words, the dominance of Korean American retailers could not have persisted through the decades without the tactics utilized by Korean American retailers themselves - i.e., without their agency.

For African American consumers in this ethnically misaligned market, the offenses of out-group producers are many. Consumers charge that Korean Americans have monopolized the ethnic beauty products market, ${ }^{148}$ shutting out African American retailers by stifling the flow from wholesalers. ${ }^{149}$ And if African Americans have created new beauty products, Korean American retailers refuse to carry them. ${ }^{150}$ African Americans have leveled so many charges at Korean American retailers that the Internet is replete with these claims and the producer-consumer relationship is clouded by a generalized, if amorphous, mistrust. ${ }^{151}$

In truth, the relationship between African American consumers and Korean American suppliers had been poised for decades, for reasons beyond the inability of competitors to penetrate the hair markets. ${ }^{152}$ African Americans had long

147 See supra note 82

148 Lloneau, supra note 16 ("The Koreans control over $85 \%$ of all ethnic hair care products sold in Beauty Supply Stores without regard as to who is the manufacture.").

149 MadameNoire, Why Do Koreans Own The Black Beauty Supply Business?, Sept. 27, 2010, https:// madamenoire.com/104753/why-do-koreans-own-the-blackbeauty-supply-business/ [https://perma.cc/AKY3-VF56 ] ("Today, there are over 9,000 Korean-owned beauty supply stores serving a billion dollar market for Black hair. Between manufacturing, distributing and selling these hair care products, Korean entrepreneurs appear to control all major components. . . . [T] here are only four central distributors serving beauty supply stores in the country and these Korean owned distributors discriminate against Black store owners in order to maintain their monopoly in the market.").

150 See BLACK HAIR, supra note 107.

151 See supra notes 106, 141.

152 See Claire Jean Kim, Bitter Fruit: The Politics of Black-Korean CONFLICT IN NeW YORK CITY (2000); Heon Cheol Lee, Conflict between Korean 
complained of mistreatment by Korean-owned businesses and periodically organized boycotts against them. ${ }^{153}$ In 1992, these old grievances exploded into protests that destroyed Korean businesses in Los Angeles after the acquittal of Latasha Harlins's killer and Rodney King's assailants. ${ }^{154}$

Charges of exclusion find some support in the literature from sociology about ethnic entrepreneurship. Consistent with Wilson and Martin's finding that Cuban American entrepreneurs pool resources within their co-ethnic communities, 155 Korean American retailers deal almost exclusively with Korean and Korean American wholesalers. ${ }^{156}$ Wholesalers are more likely to extend credit, offer installment payment plans, and sell at lower prices to co-ethnic retailers, which can be important to thinly capitalized startups. ${ }^{157}$ A degree of informality characterizes Korean American in-group commercial transactions; rather than checking a supplier's credit, wholesalers often transact through "handshake deals." 158 These busines customs are emblematic of what sociologists call "vertical integration," whereby materials are sourced from, spending restricted to, and wealth retained in co-ethnic communities. ${ }^{159}$ Conceptually, the application of vertical integration to an entire ethnic group is slightly different than the approach of antitrust law, which tends to examine vertical integration at the firm or industry level. Nonetheless, ethnic cohesion characterizes Korean American ventures in a variety of industries, mostly concentrated in low-income communities of color, from apparel to ethnic beauty supplies.

Merchants and Black Customers: A Structural Analysis, in KOREANS IN THE HOOD: CONFLICT WITH AFRICAN AMERICANS 113 (Kwang Chung Kim ed., 1999).

153 See KIM, supra note 145, at 145-46.

154 See Park, supra note 61; Oliver et al., supra note 61.

155 See Wilson \& Martin, supra note 77.

${ }^{156}$ Lee, supra note 73.

${ }^{157} \mathrm{Id}$.

${ }^{158} \mathrm{Id}$.

${ }^{159}$ Id.; Wilson \& Martin, supra note 77. 
While a vertically integrated wig and hair extensions market keeps wealth from flowing out of the Korean American community, it excludes participation by African American competitors. Given the market's evolution, very few African American suppliers of wigs and hair products exist, 160 and they have been unable to procure hair products from Korean American distributors. ${ }^{161}$ African American manufacturers have also faced difficulty convincing Korean American retailers to carry their products. ${ }^{162}$ This can be attributed partly to language barriers; for product catalogs and even industry magazines are frequently published only in Korean. ${ }^{163}$ Yet Korean and Korean American wholesalers have banded together in the past to shut out competitors, going well beyond the passive exclusion of language.

In 1975, the Department of Justice brought suit against the Korean Hair Goods Association of America, Inc. (the "Association") for (i) conspiring to regulate the price and resale conditions of imported wigs and (ii) excluding wig importers and distributors from the resale market. ${ }^{164}$ The Association was a New York organization whose members imported wigs and hair products from Korea for wholesale and retail in the U.S. ${ }^{165}$ Noting that most wigs sold in the U.S. are made out of synthetic fibers

160 But see Black-Owned Brands, supra note 139. https://18530fa3-d2e0-49d5a67b-

522187070841.filesusr.com/ugd/182cb9_81b90ee249eb43f288e60510c6938688. pdf.

161 MadameNoire, supra note 142.

162 See BlACK HAIR, supra note 107, at frame 5:50 (Kizure, a Black-owned manufacturer of curling irons and other styling tools, allegedly blacklisted from Korean American-owned shops).

163 See, e.g., BEAUTY TIMES: THE MAGAZINE FOR THE ETHNIC BEAUTY INDUSTRY, http:/ / www.beautytimes.com/ (last visited Aug. 6, 2020). See also BLACK HAIR, supra note 107, at frame 2:57.

164 See U.S. Dept. of Justice, Notice of Proposed Consent Judgment and Competitive Impact Statement Thereon, 40 Fed. Reg. 57696 (1975) [hereinafter DOJ Consent Decree Notice].

$165 \mathrm{Id}$. at 57698. 
and that the "vast majority" of synthetic wigs are manufactured in South Korea and imported to the U.S., 166 the Department of Justice contended that the Association regulated the price and distribution of wigs by restricting its membership and working with an association South Korean wig manufacturers and exporters (the "KEA") to channel the distribution of wigs through the Association. ${ }^{167}$ Although DOJ brought suit under Section 1 of the Sherman Act, 168 this was a scheme of using exclusion to facilitate price maintenance, as seen in classic Section 2 cases. ${ }^{169} \mathrm{In}$ the end, the consent decree enjoined the Association from: (i) fixing wig prices, (ii) preventing the procurement of wigs for resale, informational exchanges designed to fix prices, (iii) communicating its membership to the KEA, and (iv) unreasonably restricting its membership. ${ }^{170}$

The Association's consent decree offered a lens into how the Korean American distribution chain for wigs and hair extensions was able to consolidate its hand in the U.S. market. However, it is tantalizingly short. It also stands as the only proceeding that delves into the workings of this market with any rigor. Ultimately, the Justice Department's legal action shows that the charges of African American consumers and competitors are not mere speculation-that as far back as 1972, the Korean American distribution chain was attempting to fix prices and resale conditions for wigs and hair extensions. ${ }^{171}$ To fill in the analytical gaps in the consent decree and infuse the charges of African American consumers and competitors with rigor, we must work through the requisite steps under antitrust law. Otherwise, the charges languish in imprecision. The next Section undertakes that work.

$166 \mathrm{Id}$.

167 Id.

168 See U.S. v. Korean Hair Goods Ass'n of Am., Inc., 1976 WL 1219 (S.D.N.Y.).

169 E.g., NCAA v. Board of Regents of the University of Oklahoma, 468 U.S. 85

(1984); JTC Petroleum Co. v. Piasa Motor Fuels, Inc. (7th Cir. 1999).

${ }^{170}$ Korean Hair Goods Ass'n of Am., Inc., 1976 WL.

17140 Fed. Reg. at 57698. 


\section{Market POWER OF KOREAN AMERICAN RETAILERS}

This Section uses antitrust theory and doctrine on market power to more clearly frame the presence of Korean American retailers. To be condemned, many exclusionary and coordinating practices require a finding of market power as the very first step. ${ }^{172}$ Market power is easy to express conceptually - the power of a producer to raise prices above competitive levels - but often difficult to prove in practice. 173

Frequently, market power is gauged through the indirect steps of defining the relevant market and then measuring the defendants' market shares. While the market definition/market share paradigm has come under assault through the decades, ${ }^{174}$ it remains the most popular means of assessing market power. More importantly for our purposes, this paradigm generates broader insights about the preferences and pressures of African Americans, which might be missed if we were to assess market power more directly-for instance, by going straight to anticompetitive effects. ${ }^{175}$

This Section begins by discussing the application of the market definition/market share paradigm to the retail of wigs and hair extensions to African Americans. The it moves onto other conceptualizations of market power. It concludes with an examination into how antitrust doctrine would have to be expanded for African American competitors and consumers to bring suit against Korean American producers.

172 HOVENKAMP, supra note 17 , at $\S 3.1$.

173 At its core, market power gauges the difference between position of the accused firm and a competitive counterfactual. Daniel A. Crane, Market Power Without Market Definition, 90 Notre DAME L. REV. 31, 37 (2014).

174 See, e.g., See Louis Kaplow, Why (Ever) Define Markets?, 124 HARV. L. REV. 437, 440 (2010).

175 This is especially the case for dynamic industries. See Shelanski, Information, Innovation, and Competition Policy for the Internet, U. PA. L. REV. 1663, 1673-74 (2013). 


\section{A. Oblique Measures of Market Power}

\section{Market definition}

For wigs and hair extensions, market definition is not difficult, but the exercise can be enlightening. ${ }^{176}$ Despite our preliminary focus on the products themselves (e.g., wigs), the complaints of monopoly and monopolization emanate from the retail market, where the interaction between consumers and producers happens to be most ethnically misaligned. In the retail of wigs and hair extensions to African Americans, which occurs mostly in brick and mortar stores, commerce is dominated by Korean American-owned shops. ${ }^{177}$ Consumer-producer frictions coincide with-and are therefore augmented by-interracial tensions.

The product market clearly encompasses brick and mortar stores, where African American women typically procure wigs and extensions. Stores provide convenient access to myriad products; consumers can easily compare prices, textures, and colors, especially for last-minute purchases prior to a trip to the salon. Demand, especially in the form of traditional storefronts, is inelastic - one of the two common features of a precisely defined market (the other feature being supply inelasticity). ${ }^{178}$

Demand for wigs and extensions is inelastic due to social preferences that are often infused into law. In the U.S., long, straight hair is favored over other styles, a predisposition that

176 Wigs and extensions are also lumped together in BLACK HAIR, supra note 107, at frame 0:28 ("Even though African Americans make up only 10\% of the American population, they buy $70 \%$ of all wigs and extensions ...").

177 See Lloneau, supra note 16; Sapong, supra note 107; MadameNoire, supra note 141.

178 HOVENKAMP, supra note 17, at 93. 
reflects the markers of whiteness. ${ }^{179}$ Because blackness is defined in opposition to whiteness, 180 the natural hair of African Americans, who are racialized as Black, has often been viewed as undesirable. ${ }^{181}$ Thus, products from relaxers to hair extensions cater to these preferences. ${ }^{182}$ Of course, social preferences are fluid, and natural hair has been celebrated, if episodically. 183

The law has internalized these norms into its systems of incentives. In several jurisdictions, employers can fire or demote employees for how they wear their hair, with no repercussions. ${ }^{184}$ Hair discrimination cannot necessarily be couched as legally actionable discrimination under Title VII. ${ }^{185}$ And the closer one gets to the textured appearance of natural hair, the more one

179 See Angela Onwuachi-Willig, Another Hair Piece: Exploring New Strands of Analysis under Title VII, 98 GEO. L.J. 1079, 1193 (2010) ("society's normative ideal for women's hair [is] straight hair, which hangs down as it grows longer - hair that is not naturally grown by black women").

180 FlOYA ANTHIAS \& NiRA YUVAL-DAVIS, RACIALIZED BOUNDARIES: RACE, NATION, GENDER, COLOUR, AND ClASS AND THE ANTI-RACIST STRUGGLE 1992); CAROL ANDERSON, WHITE RAgE: THE UNSPOKEN TRUTH OF OUR RACIAL DiVIDE (2016); IAN HANEY LOPEZ, WHITE By LAW: THE LEGAL CONSTRUCTION OF RACE (2d 3d. 2006).

181 Onwuachi-Willig, supra note 160, at 1107 ("In a society where straight, long, fine hair (compared to black hair) is viewed not only as the norm but as the ideal for women, tightly coiled black hair easily becomes categorized as unacceptable, unprofessional, deviant, and too political."). See also Matt Donnelly, Inside 'America's Got Talent': Ousted Judges Had Complained of Toxic Culture, VARIETY, Nov. 26, 2019 (actress Gabrielle Union criticized by the producers of the show America's Got Talent for hairstyles that were "too black"). 182 Roseborough \& McMichael, supra note 104, at 105 ("relaxer is a chemical compound applied at varying intervals to permanently break hydrogen disulfide bonds along the hair shaft and release the tight curl pattern.").

183 E.g., 1960s, black is beautiful movement, and arguably today.

184 See D. Wendy Greene, Title VII: What's Hair (And Other Race-Based Characteristics) Got To Do With It?, 79 U. Colo. L. ReV. 1355, 1370-75 (2008) (analyzing Eatman v. United Parcel Service, 194 F. Supp. 2d 256 (S.D.N.Y. 2002) and other cases).

185 Greene, supra note 165. 
hazards exclusion, termination, or demotion. ${ }^{186}$ Even where legal protections exist, African Americans understand that natural or natural-looking hair can hinder professional advancement. ${ }^{187}$

Although we are defining our market as the retail of wigs and extensions, it is still illuminating to analyze the products sold. One theme that emerges from doing so is the socially embedded inelasticity of demand for items that produce straight hair. This inelasticity spills over to retail and puts consumers at the mercy of retailers. ${ }^{188}$ The second theme is that not all African American hair products are fungible. Even though many products have been invented to alter the length and texture of African American hair, 189 these products are not reasonably interchangeable because the associated processes are different: relaxers chemically alter the texture of hair coils, sometimes at the risk of chemical burns, while wigs and extensions are worn over hair to alter the apparent length and curl pattern. And interchangeability is the hallmark of market definition: all products that are reasonably interchangeable, or can substitute for one another, must factor into product market definition. 190

Even within wigs and extensions, we can further distinguish products on two additional fronts. First, there is a difference

186 In Eatman, African American UPS drivers were told to cover "unconventional" hairstyles, "which included dreadlocks, braids, corn rolls, a dew rag, and a ponytail. 194 F. Supp. 2d at 259.

187 See Donnelly, supra note 162.

188 The consequences are not merely economic. African Americans have long complained of condescending treatment by Korean American shopkeepers, a complicated dynamic that is informed partially by the need for products sold and the lack of alternative venues. See. . . Of course, counterexaplmes abound. See ... stories of solidarity

189 See Roseborough \& McMichael, supra note 104, at 104-06; Onwuachi-Willig, supra note 162, at 1089.

190 See U.S. v. E.I. du Pont de Nemours \& Co., 351 U.S. 377, 394, 400, 404 (1956); Brown Shoe Co. v. U.S., 370 U.S. 294, 325 (1962). This is the concept of crosselasticity: where substitutes are many, cross-elasticity is high. Yet interchangeability and cross-elasticity are prone to error. See Kaplow, supra note 156, at 482-91 (explaining why elasticity should be emphasized over crosselasticity). 
between products that replicate tighter curls versus products that mimic straight hair. Wigs and extensions might perform similar functions, more textured hairpieces might not be good substitutes for straight hairpieces. Second, there is a difference between wigs and extensions made from human hair and those made from synthetic materials. The former is much higher quality and more expensive than the latter; and even within human hair, there are gradations. ${ }^{191}$ For our purposes, we focus on human hair, which entails a different supply chain than synthetic hair. Again, we note that wigs and hair extensions are not the same as the venue in which they are sold - here, we focus primarily on the latter.

As for supply elasticity, assessment comes with complications as well. After displacing door-to-door salespeople, storefronts enjoyed a decades-long lock on the retail market. Offering immediate access to a variety and large quantities of products, traditional stores seem to have even fended off challenges from newer outlets such as Internet sales and salondriven sales. ${ }^{192}$ Our market should be defined as all retailers to encompass these newer outlets; even so, with brick and mortar stores predominating, the daylight is slim between all retailers and physical stores.

Nonetheless, supplier elasticity is difficult to pin down because there is a glut of firms in any geographic market for consumers to choose from - those firms just happen to be mostly owned and operated by Korean Americans. In the retail of wigs and hair extensions to African Americans, competition is intense. It was intraethnic competition, after all, that helped drive the industry toward decline in the 1970s. ${ }^{193}$ Yet despite the abundance of retailers, there are very few non-Korean alternatives. Can it be said, then, that this market is characterized by supplier inelasticity if we consider only the number of firms? Whatever the

${ }^{191}$ For example, Remy hair, where cuticles are intact and going in the same direction, is considered to be higher end.

192 See infra notes 187 and 188 and accompanying discussion.

193 YOON, supra note 12, at 112-13. 
conclusion, the picture of a supply network that competes intensely within itself but cooperates to exclude competition from out-group insurgents.

To be sure, challengers have managed to break through. Instead of procuring wigs and extensions from Korean wholesalers, however, they rely on nontraditional sourcing. Mayvenn, a Black-owned retailer that started in 2012 and is funded by Serena Williams and venture capital powerhouse Andreessen Horowitz, sources hair from China and sells either directly to consumers or through salons. ${ }^{194}$ Indique, co-founded in 2007 by African American and Indian American partners, sources from India, where hair is donated as part of religious ceremonies, and sells products through its proprietary salons. ${ }^{195}$ The extent of consumer preference for these upstarts is difficult to quantify, these alternatives do not command a substantial share of the product market yet. ${ }^{196}$

As a harbinger of imminent troubles, U.S. Customs and Border Protection recently seized 13 tons of shipments of human hair imports from China. ${ }^{197}$ The hair was alleged to have been shorn from Uighur internees at concentration camps in Xinjiang,

194 Susan Adams, Long on Hair: The World's First Venture-Backed Human-HairExtension Company Wants To Be The Airbnb of Salons, FORBES, Sept. 27, 2019; About Us, MAYVENN, https:// shop.mayvenn.com/about-us (last accessed July 30, 2020).

195 See Our Company, INDIQUE HAIR EXTENSIONS, https://www.indiquehair.com/pages/our-company (last accessed July 30, 2020).

196 Mayvenn has been valued at $\$ 100$ million, while the entire hair extensions market is valued at $\$ 6$ billion. See Adams, supra note 176. Its valuation does not necessarily reflect its current share of the market, only its potential. Of course, much more in-depth empirical work must be done to break out exactly how much of that $\$ 6$ billion figure pertains to African American consumers and what share Mayvenn and traditional retailers control of that sector.

197 Withhold Release Orders and Findings, U.S. Customs and Border Protection, https://www.cbp.gov/trade/programs-administration/forced-

labor/withhold-release-orders-and-findings (search under "China" and entries 33 and 34 for "Hair Products"). 
western China, for Muslim minorities. ${ }^{198}$ Muslim internment is one of the worst ongoing violations of human rights in the world;199 any supply chain entangled, or even alleged to implicate, the labor or body parts of internees could stain an entire industry. ${ }^{200}$ At the very least, if Chinese hair continues to generate controversy, then it will prove to be an unstable source for insurgent retailers such as Mayvenn.

\section{Market share calculation}

With the above considerations in mind, let us define the market as the brick-and-mortar retail of wigs and extensions made from human hair for consumption by African Americans. From here, market share calculation can reveal with greater precision the extent of dominance by Korean American suppliers. By most accounts, Korean American businesses control approximately 70-85 percent of the "ethnic beauty products" market. ${ }^{201}$ Vastly more research must be done to measure the market share of Korean American businesses in the relevant markets. However, the anecdotal evidence from African American consumers is that purchasing wigs and hair extensions invariably requires navigating Korean-owned stores. ${ }^{202}$

Even if "saturation" of the relevant markets by Korean American businesses is assumed, market share analysis will

\footnotetext{
198 See Martha Mendoza, U.S. Customs Seizes 13-Ton Shipment of Human Hair Weaves, Believed to Have Been Cut From Prisoners in Chinese Internment Camps, TIME, July 1, 2020; Shalway Evans, That Hair You Just Bought Could Be From an Internment Camp in China, ESSENCE, July 2, 2020.

199 See Lindsay Maizland, China's Repression of Uighurs in Xinjiang, COUNCIL ON FOREIGN RELATIONS (June 30, 2020), https://www.cfr.org/backgrounder/chinas-repression-uighurs-xinjiang; Marlise Simons Uighur Exiles Push for Court Case Accusing China of Genocide, N.Y. Times, July 6, 2020.

200 See Mendoza.

201 See, e.g., Sapong, supra note 107 (70\%); Lee, supra note 73 (80\%); Lloneau, supra note $16(85 \%)$.

202 See, e.g., BlACK HAIR, supra note 107.
} 
almost certainly fail traditional measures of concentration because numerous small firms play in our ESM market. Customarily, market dominance is attributed to one very large producer (a monopoly) or a small number of fairly large producers (say, an oligopoly of four or five producers). ${ }^{203}$ Yet because producers are small and compete intensely, this feature belies our typical understanding of concentration.

Very few detailed studies have been conducted on the numbers of ethnic beauty stores (where wigs and extensions are sold) in a geographic market. One study by the sociologist Jennifer Lee, who relied on interviews with Korean proprietors, pegged the number of ethnic beauty supply stores in New York City at 300, with 80 percent of them "Korean owned." 204 Professor Lee's interviews took place in three largely African American neighborhoods in New York: East Harlem, West Harlem, and Jamaica, Queens. ${ }^{205}$ While she does not specify the numbers of stores in each neighborhood, we can take Jamaica as an example and assume that (1) it comprises a relevant geographic market and (2) it has 20 such stores. ${ }^{206}$ Further, if we assume that the intense competition among Korean American retailers yields a

${ }^{203}$ Of course, the power of numerous small producers can be augmented if they band together - say, through a trade association. In American Colum \& Lumber Co., for example, the American Hardwood Manufacturers' Association was comprised of approximately 400 members, with 365 of them engaged in the information exchange plan. 257 U.S. 377, 391 (1921). In National Society of Professional Engineers, the society's worldwide membership was 69,000, and consulting engineers, who were at the heart of the no-bid rule, numbered 12,000. 435 U.S. 679, 682 (1978).

${ }^{204}$ Lee, supra note 73.

$205 \mathrm{Id}$.

206 The African American population in Queens is 148,800 (62\% of 240,000 residents). https://furmancenter.org/neighborhoods/view/jamaica-hollis. This comprises approximately 7.5\% of New York's 1.992 million African Americans. https://www.census.gov/quickfacts/newyorkcitynewyork. If we take Professor Lee's figures to be accurate, $7.5 \%$ of 300 is 22.5 ethnic beauty stores for our geographic market. Indeed, a quick Google maps search of "ethnic beauty supply Jamaica Queens" returns 22 results. 
market where no single supplier runs away with market share, then our shares might look something like this:

\begin{tabular}{|l|l|l|l|}
\hline Firm & Market Share (\%) & Firm & Market Share (\%) \\
\hline 1 & 13 & 11 & 4 \\
\hline 2 & 12 & 12 & 4 \\
\hline 3 & 8 & 13 & 3 \\
\hline 4 & 7 & 14 & 3 \\
\hline 5 & 6 & 15 & 3 \\
\hline 6 & 6 & 16 & 3 \\
\hline 7 & 5 & 17 & 2 \\
\hline 8 & 5 & 18 & 2 \\
\hline 9 & 5 & 19 & 2 \\
\hline 10 & 5 & 20 & 2 \\
\hline
\end{tabular}

Table 1. Hypothetical Market Shares in a Relevant Geographic Market

We can start with the $k$-firm concentration ratio, setting $k$ at 4 to get the commonly utilized four-firm concentration ratio, or the sum of the market shares of the four largest firms in the market. Here the four-firm ratio would be $40 .{ }^{207} \mathrm{~A}$ more precise measure is the Herfindahl-Hirschman Index ("HHI"), or the sum of the squares of the market shares of all firms. Under the above hypothetical, the HHI would be 682, which does not even cross the threshold of moderate concentration. ${ }^{208}$

If all but three of firms (assume, e.g., Firms 7-10) were owned by Korean Americans, then the Korean-owned firms would

207 See, e.g., William G. Shepherd, Concentration Ratios, in NeW PALGRAVE DictionaRY OF ECONOMICS (1st ed. 1987); Dep't of Justice, Merger Guidelines (1968).

208 U.S. Department of Justice \& FTC, Horizontal Merger Guidelines § 5.3 (2010). The HHI is the more commonly used index of concentration today, but both measures have their flaws. HHI captures the differences in firm size more accurately but errs on overestimating the importance of that difference, while the four-firm concentration ratio overlooks and undervalues firm size disparity. HOVENKAMP, supra note 17, at $§ 12.4 \mathrm{a} 2$. 
occupy $80 \%$ of the market, but concentration is typically not measured in this way. ${ }^{209}$ Instead, concentration is assessed at the level of individual firms.

While the above illustration is purely conjecture, it incorporates an important insight from the literature on Korean American small businesses: that they crowd into specific niches and compete intensely against one another. ${ }^{210}$ The success of one enterprise prompts others to start a competing enterprise, often in close proximity to the first. ${ }^{211}$

\section{B. Retailer Diversity}

Our defined market would likely not qualify as concentrated under the market definition/market share paradigm. However, there are other measures of market power whose application to antitrust maybe be more appropriate, if experimental. As a salient example, economists have proposed looking at the way ecologists measures biological diversity, by assessing the richness and evenness of a geographical habitat, where richness "is the number of different kinds of organisms or species" and evenness "compares the similarity of the population size of each of the species." 212 Applying these measures to the market for wigs and hair extensions, we would find that richness is negligible, and evenness skews toward a lopsided quantity of Korean American firms. This result is equivalent in ecology to a habitat dominated by one species. 213

\footnotetext{
${ }^{209}$ Note that Black Owned Hair Care Challenge only has one African American retailer listed for Queens. See https://18530fa3-d2e0-49d5-a67b522187070841.filesusr.com/ugd/182cb9_81b90ee249eb43f288e60510c6938688. pdf.

210 See YOON, supra note 12, at 112-13.

$211 \mathrm{Id}$.

212 Paolo M. Adajar et al., The Surprising Hybrid Pedigree of Measures of Diversity and Economic Concentration 11, Working Paper 26512 (2019), http://www.nber.org/papers/w26512.

${ }^{213} \mathrm{Id}$.
} 
Biologists and ecologists quantify richness and evenness through the Simpson's Diversity Index, which expresses the probability "that two organisms chosen at random and independently from the population will be found to belong to the same species." 214 The Index shifts the analysis from the level of individual organisms to the level of species. Incidentally, HHI incorporates aspects of richness and evenness as well; for instance, squaring firm market shares augments the effect of (and therefore accounts for) disparities in firm size. Still, the Simpson's Diversity Index gives us license to think of a market in terms of its producer diversity, providing the theoretical basis to look beyond individual firms and at the level of ethnic groups.

The Simpson's Diversity Index has not been adapted to antitrust contexts, ${ }^{215}$ though diversity has featured prominently in some antitrust-adjacent areas of law. Telecommunications law, for instance, has grappled with viewpoint diversity in the midst of media consolidation, ${ }^{216}$ with the Federal Communications Commission once proposing a diversity index based on the HHI to identify media markets where cross-ownership limits should be retained. ${ }^{217}$ Antitrust scholars have also suggested alternatives to the narrow focus on price and efficiency, upholding diversity in markets where rivals compete on nonprice differentiation. ${ }^{218}$ In close cases such as ours, where traditional market power

${ }^{214}$ Id. at 12. See also Edward H. Simpson, The Measurement of Diversity, 163 NATURE 688 (1949).

${ }^{215}$ But see Miriam Marcowitz-Bitton \& Jacob Nussim, Regulation of Book Markets, 97 WASH. U. L. REV. 835, 895 n.425 (2020).

216 See Daniel E. Ho \& Kevin M. Quinn, Viewpoint Diversity and Media Consolidation: An Empirical Study, 61 STAN. L. REV. 781 (2009).

217 See Report and Order and Notice of Proposed Rulemaking, 18 F.C.C.R. 13620, 13775 (2003). After legal challenges, the index was dropped See Prometheus Radio Project v. F.C.C., 373 F.3d 372 (3d Cir. 2004).

218 See Neil W. Averitt \& Robert H. Lande, Using the "Consumer Choice" Approach to Antitrust Law, 74 ANTITRUST L.J. 175 (2007). Relatedly, on the use of competition law to advance small and medium-sized businesses, particularly in countries where an ethnic minority controls commerce, see Fox, supra note 43. 
paradigms yield ambivalent results, diversity might call for antitrust intervention.

The wig and extensions market is an apt setting to test the viability of principles such as diversity and consumer choice. Retailers compete intensely, eroding margins and pushing prices toward convergence. ${ }^{219}$ The products themselves are fairly homogenous, varying only in texture, length, and curl pattern. What distinguishes retailers from one another, then, is convenience, selection, and, perhaps most importantly, the ethnic identities of each firm's managers and owners. These three factors-convenience, selection, and identity-are important to consumers and balance one another in nuanced ways. Yet only the ethnic identities of retailers are meaningful to market power. From that standpoint, the prevalence of Korean American-owned firms makes this market extremely concentrated, with this group wielding market power.

There are reservations, though, with this conceptualization of diversity, which pits Korean American retailers against African American competitors and consumers. Racial and ethnic formation is a dynamic, contested process, ${ }^{220}$ but this strain of market power analysis reduces Korean Americans to one homogenous block and African Americans to another, extrapolating the degree of diversity from their ratio. In reality, so many factors influence racial and ethnic formation that it is understood to be ever fluid. ${ }^{221}$ Racial order is transient and should be historically situated.222 To the extent that race signifies "social conflicts and interests" embedded in human bodies, ${ }^{223}$ its meaning constantly shifts as those conflicts and interests reorient themselves.

219 YOON, supra note 12, at 112-13.

220 NADIA Y. KIM, IMPERIAL CITIZENS: KOREANS AND RACE FROM SEOUL TO LA xiv (2008).

${ }^{221}$ Omi and Winant break race into three critical factors: ethnicity, class, and nation. See OMI \& WINANT, supra note 22, at 11-13.

222 OMI \& WINANT, supra note 22, at 61.

${ }^{223} \mathrm{Id}$. at 55 . 
Among Korean American shopkeepers, whom we presume to constitute a uniform block for the purpose of assessing market power, there are notable differences. Many did not stand with Soon Ja Du, who fatally shot Latasha Harlins in 1992.224 Then, as today, Korean Americans have worked with African Americans to build up their communities in pan-racial solidarity. ${ }^{225}$ More pointedly, Korean American retailers may be pursuing divergent sourcing strategies. The re-entry of China as a global hair supplier, 226 coupled with Internet platforms such as Alibaba, allows Korean American retailers to bypass co-ethnic wholesalers just as much as it allows African American competitors an alternative source of products.

The above factors complicate the picture of Korean American solidarity, either as an ethnic unit or as a production unit. Ultimately, then, any metric of market power that aggregates the multitudes of discrete retailers, even if to assess market diversity, does so at the expense of intraethnic nuance.

\section{Anticompetitive Effects}

Finally, to avoid the pitfalls of market diversity and market definition/market share, we can attempt to detect market power through direct evidence of anticompetitive effects. ${ }^{227}$

\footnotetext{
${ }^{224}$ KIM, supra note 213 (L.A. Korean community asserting Du was "mentally unbalanced"). The community also blamed mainstream American media for inflaming violence, by relentlessly airing footage of the shooting, glossing over White mistreatment of both Korean Americans and African Americans. Id. at 73.

225 Of course, episodes such as Los Angeles 1992 can reinforce ethnic cohesion. Kim, supra note 83.

226 I say "re-entry" because in the 1960s, China was a significant supplier until the U.S. banned the import of Chinese hair products. BLACK HAIR, supra note 106.

227 See United States v. Microsoft Corp., 253 F.3d 34, 51 (D.C. Cir. 2001) (direct evidence of Microsoft's monopoly power).
} 
Unfortunately, there is as much disagreement over what constitutes direct evidence as there is over market definition. ${ }^{228}$

One long-established form of direct evidence is exclusionary conduct; for courts have inferred market power from the power to exclude competition. ${ }^{229}$ In our case, this requires looking to the upstream market of wig and extensions wholesale and distribution, which is a necessary input into the retail of these products. An exclusionary strategy might proceed as follows: a consortium of wig and extensions wholesalers and distributors, all Korean American firms, refuses to sell products to nonKoreans. The consortium might explicitly refuse to deal with any non-Korean retailers, or it might conspire with South Korean wig manufacturers to export only to the consortium, rather than selling directly to any retailer based in the U.S. This was the very strategy of the Korean Hair Goods Association of America, Inc. (the "Association") when DOJ brought suit in 1975. The Association collaborated with the association of South Korean wig manufacturers and exporters ("KEA") to restrict the flow of wigs to its competitors in the U.S. by, among other strategies, mandating that import and distribution flow through the Association rather than directly to retailers. ${ }^{230}$ Because most wigs were manufactured in Korea at the time, 231 this maneuver choked off the supply line for out-group competitors. KEA and the Association both enjoyed market power in their respective markets - the manufacture and export of wigs in South Korea and the important and distribution of wigs into the U.S.

228 See Crane, supra note 166, at 45 (summarizing seven mechanisms of direct evidence from lower court decisions).

229 See id. at 45 n.82 (citing Heerwagen v. Clear Channel Commc'ns, 435 F.3d 219, 227 (2d Cir. 2006); Geneva Pharms. Tech. Corp. v. Barr Labs. Inc., 386 F.3d 485, 500 (2d Cir. 2004); PepsiCo., Inc. v. Coca-Cola Co., 315 F.3d 101, 107 (2d Cir. 2002); Conwood Co. v. U.S. Tobacco Co., 290 F.3d 768, 783 n.2 (6th Cir. 2002); Tops Mkts., Inc. v. Quality Mkts., Inc., 142 F.3d 90, 98 (2d Cir. 1998)).

230 See DOJ Consent Decree, 40 Fed. Reg.

${ }^{231} \mathrm{Id}$. at 57698. 
To a large extent, claims of exclusion have not abated today. African American retailers routinely complain that Korean wholesalers refuse to deal with them, thereby shutting them out of hair products to resell. ${ }^{232}$ However, exclusion as an indicator of market power is difficult to square, both doctrinally and within the wig and extensions market specifically.

While some courts have endorsed the inference of market power from exclusionary conduct, ${ }^{233}$ this inference is beset by circularity because recovery for exclusion is permitted only if the alleged excluder possesses market power. 234 One widely recognized exception to this circularity is where the excluders are able to raise their rivals' costs. ${ }^{235}$ Examples abound of such exclusionary schemes - for example, the foreclosure or denial of access of to a necessary input by incumbents signals their market power. ${ }^{236}$ In the wig and extensions market, the clearest instance of this type of exclusion would be any concerted effort among Korean manufacturers, wholesalers, or distributors to deny African American retailers access to hair products. If that transpires, then the insurgents would have to find new sources of

232 BLACK HAIR, supra note 107.

233 See, e.g., Brooke Groupe Ltd. v. Brown \& Williamson Tobacco Corp., 509 U.S. 209 (1993).

${ }^{234}$ Crane, supra note 166 , at 64-65.

235 See Thomas G. Krattenmaker \& Steven C. Salop, Anticompetitive Exclusion: Raising Rivals' Costs to Achieve Power over Price, 96 YALE L.J. 209 (1986)

236 This is the crux of the essential facilities claim, which is established if: (1) a monopolist controls a facility that (2) a competitor is unable to practically or reasonably duplicate and (3) use of the facility is denied to the claimant, even though (4) it is feasible for the monopolist to provide access. MCI Commc'ns Corp. v. Am. Tel \& Tel. Co., 708 F.2d 1081, 1132-33 (7th Cir. 1983). For its case law lineage, see Verizon Commc'ns Inc. v. Law Offices of Curtis V. Trinko, 540 U.S. 398, 415 (2004); Aspen Skiing Co. v. Aspen Highlands Skiing Corp., 472 U.S. 585, 611 (1985), Otter Tail Power Co. v. United States, 410 U.S. 366, 382 (1973), and United States v. Terminal R.R Ass'n of St. Louis, 224 U.S. 383, 41113 (1912). For examples, see, e.g., [prior work redacted for anonymity]. For theoretical support, see Patrick Rey \& Jean Tirole, A Primer on Foreclosure, in 3 HANDBOOK OF INDUSTRIAL ORGANIZATION 2147, 2155 (Mark Armstrong \& Robert H. Porter eds., 2007). 
raw materials (e.g., hair from India) and possibly manufacture the hair products themselves. ${ }^{237}$ Or insurgents would have to source manufactured products from someplace other than South Korea. 238

Proving exclusionary conduct by Korean American importers, wholesalers, and distributors is not difficult. There appear to be only a few such firms (as opposed to nearly 10,000 retailers), which more easily facilitates coordination; collectively, these firms wield market power. ${ }^{239}$ It is an altogether different matter, however, to prove that this exclusion raises the costs of African American retailers. The rise of China as a source of wigs and extensions may be drastically cutting suppliers' costs. Relatedly, the fact that hair in India is donated means that raw material costs might be even lower if South Korea is bypassed. More work must be done to figure out the margins of sourcing from South Korea versus China and India. For now, the fact that some African American competitors are thriving-and two are outright thriving - amidst the exclusion undercuts any argument of Korean market power.

Exclusion is commonly a consequence of vertical integration. Wholesalers and resellers, or an upstream facility and a downstream monopolist, must be unified to some degree for them to foreclose markets or raise rivals' costs. To be sure, ethnic bonds go a long way toward fostering commercial cohesion, 240 but the vertical integration of Korean wholesalers and Korean American retailers is not frictionless. Although outsiders cannot easily peer into these relations, we can glean some insights from the public record of litigation. The handful of cases implicating Korean American wig and extensions retailers reveals that manufacturers and wholesalers can be extremely demanding of retailers, pressing them to agree to quotas of regular shipments, backed by

\footnotetext{
237 This appears to be the Indique model. See Our Company, supra note 188.

238 This appears to be the Mayvenn model. See Adams, supra note 176.

239 See BLACK HAIR, supra note 107.

240 Wilson \& Martin, supra note 77.
} 
personal guarantees. ${ }^{241}$ More generally, these cases show that ethnic beauty supplies is a rough-and-tumble industry, where business partners can turn on one another. ${ }^{242}$ Co-ethnic bonds must therefore not be presumed.

Of course, this may also be an industry where in-group incumbents compete intensely against one another but are willing to band together to stymie out-group insurgents. This is the model from other markets such as finance. ${ }^{243}$ Yet those markets are typically dominated by a small oligopoly of large producers. Here, we are dealing with a large and diverse world of small retailers.

Nonetheless, if Korean American firms are analyzed as a cohesive unit, then their staying power would push antitrust toward finding an offense and devising a remedy-either for express coordination or, more experimentally, parallel exclusion. If competitors or consumers can produce evidence of express coordination, then this market would show that collusive and exclusionary scheme may be more stable than antitrust theory holds. ${ }^{244}$ This determination may depend on the intuition from sociology that an ethnic group withdraws into itself, strengthening co-ethnic bonds, when threatened by exogenous forces. ${ }^{245}$ Here the external threats would be competition and interracial tensions. Alternatively, at the wholesale level, Korean American firms may well be determining independently (rather than working together) to deny out-group rivals access to a necessary input. Even still, antitrust doctrine around noncooperative oligopolies may regard this as a form of parallel exclusion that militates toward intervention. ${ }^{246}$

\footnotetext{
${ }^{241}$ Daweoo Int'l (America) Corp. v. Chade Int'l, Inc., 1992 WL 175600.

242 See T3Micro, Inc. v. SGI Co., Ltd., 2010 WL 11597603.

243 See [prior work redacted for anonymity].

244 See, e.g., Selten, supra note 19; Levenstein \& Suslow, , supra note 19; Dick, , supra note 19.

245 See Turner \& Bonacich, supra note 21.

246 See C. Scott Hemphill \& Tim Wu, Parallel Exclusion, 122 YALE L.J. 1182, 123738 (2013).
} 
Ultimately, market power is an attempt to express the delta, or difference, between the market at hand and a perfectly competitive counterfactual. ${ }^{247}$ This bears out in the various mathematical expressions of market power. ${ }^{248}$ With the advent of China and India as suppliers of hair and wigs, as well as platforms to connect retailers and even consumers with non-Korean suppliers, that delta may be diminishing. More empirical work on price and marginal cost must be done, of course, but this market may be converging toward perfect competition more swiftly than ever before.

\section{Facilitating Practices}

A finding of market power does not end the inquiry. African American challengers would have to couch their claims in conformity with antitrust doctrine, which presently does not offer many viable avenues.

One possible claim is that the actions of Korean American wholesalers and retailers, from the refusal to carry African American-made products to the refusal to extend African American retailers credit, amount to a group boycott of-or a horizontal agreement to refuse to deal with-African American competitors. At its inception, courts had subjected group boycotts

247 Crane, supra note 166, at 33 ("[M]arket power only makes sense as an expression, in relative terms, of the distance between the market as it is and a competitive counterfactual ... Since antitrust policy aims to reduce the delta between a plausible competitive counterfactual and the actual circumstances, market power should be understood as that delta--the infirmity that antitrust law could correct.").

248 E.g., the Lerner index: $\mathrm{L}=(\mathrm{P}-\mathrm{MC}) / \mathrm{P}$, where $\mathrm{P}$ denotes price and $\mathrm{MC}$ marginal cost. Here the delta is between price and marginal cost. In other words, in a perfectly competitive world, price would equal marginal cost, so the excess of price over marginal cost reveals a firm's market power. 
to per se illegality, the highest level of scrutiny in antitrust. ${ }^{249}$ Yet, as elsewhere in antitrust, condemnation of these schemes has softened in recent years, particularly where procompetitive justifications lurk. ${ }^{250}$ This swing has been so extreme that the presumption on group boycotts is now validity under a rule of reason approach, rather than illegality under a per se approach. 251

As a vertical strategy, refusal to deal in facilitation of exclusion is accorded even greater deference. Refusal to deal is often brought as an essential facilities claim against a defendant who controls a necessary input (typically, an infrastructure with network effects) into a market. ${ }^{252}$ Customarily, the defendant is a monopolist, or at least an oligopoly whose market power is indisputable. ${ }^{253}$ Yet even if African American challengers were to establish that Korean American retailers harbored market power, essential facilities has been eviscerated as a theory of harm. ${ }^{254}$ The high-water mark of the duty to deal doctrine has long passed, 255 and today's courts simply view a refusal to deal as the province of businesses.

Procompetitive efficiencies also justify information sharing, a strategy among competitors that can be challenged as a

249 See, e.g., Eastern States Retail Lumber Dealers' Ass'n v. U.S., 234 U.S. 600, 614 (1914); American Medical Ass'n v. U.S., 317 U.S. 519 (1943); Klors v. Broadway-Hale Stores, Inc., 359 U.S. 207, 212 (1959).

250 See, e.g., NYMEX Corp. v. Discon, Inc., 525 U.S. 128, 134 (1998). For analysis on this doctrine's application to an ethnically segmented market similar to the one at hand, see Barak D. Richman, The Antitrust of Reputation Mechanisms: Institutional Economics and Concerted Refusals to Deal, 95 VA. L. REV. 325, 340-46 (2009).

251 HOVENKAMP, supra note 17, at 239.

252 See supra note 236.

253 See, e.g., Otter Tail Power Co. v. United States, 410 U.S. 366, 382 (1973); Verizon Commc'ns Inc. v. Law Offices of Curtis V. Trinko, 540 U.S. 398, 415 (2004).

254 See Trinko, 540 U.S. at 410-11 ("We have never recognized [the essential facilities doctrine], and we find no need either to recognize it or to repudiate it here.") (citations omitted).

255 See, e.g., Aspen Skiing Co. v. Aspen Highlands Skiing Corp., 472 U.S. 585, 611 (1985); Otter Tail, 410 U.S. 
facilitation device for collusion and exclusion even in the absence of express agreement. Claimants might allege, for example, that the publication of product catalogs and trade journals in the Korean language operates to signal inventory pricing while shutting out non-Korean retailers. In their defense, the incumbents might point to the dominance of South Korean manufacturers and exporters as suppliers, with whom U.S. distributers and retailers can communicate more easily in Korean. The likelihood of success of these claims is difficult to quantify. On one hand, the wigs and extensions market is characterized by fungible products and inelastic demand, 256 and these information exchanges might pertain to price ${ }^{257}$ or further a group boycott. ${ }^{258}$ On the other hand, however, information exchanges are more suspect in concentrated markets, ${ }^{259}$ and African American insurgents must be able to point to some sort of actual exchange of information, ideally within the incriminating areas. ${ }^{260}$ This claim seems to turn, again, on market power, which itself turns on the appropriateness of analysis at the firm versus ethnic group level.

Efficiencies do abound in the wig and extensions market. The degree of vertical integration among co-ethnic manufacturers, distributors, and retailers means that products can be moved quickly to any locality in the U.S. Korean American retailers in African American communities can also spot new trends and transmit this information to South Korean manufacturers, who can respond rapidly. Simultaneously, the rough-and-tumble

\footnotetext{
256 See HOVENKAMP, supra note 17, at 236 (information exchange certain to be condemned if the market is concentrated, the price is fungible, and demand is inelastic).

257 See id. at 237 (price information exchanges suspicious). See also American Column \& Lumber Co. v. U.S., 257 U.S. 377 (1921); U.S. v. American Linseed Oil Co., 262 U.S. 371 (1923).

258 See Eastern States Retail Lumber Dealers' Ass'n v. United States, 234 U.S. 600 (1914).

259 See supra note 256.

${ }^{260}$ For a similar discussion, see Richman, supra note 250, at 352-55.
} 
competition among retailers means that prices should converge toward competitive, rather than supracompetitive, levels.

The central question this ESM market is therefore who is harmed: Who is harmed by the actions of Korean American firms in this market-African American consumers or competitors? If prices are competitive, the answer would not be consumers. Indeed, group boycotts, refusals to deal, and information exchanges are injurious only to competitors, with offsetting efficiencies for consumers. The very use of "ethnic misalignment" for this market suggests that it is competitors who are harmed because they are denied the chance to sell to co-ethnic consumers. ${ }^{261}$

To work through the implications, we might imagine a market in which an African American insurgent were to break through and eventually run away with market share-say, if Mayvenn or Indique were to displace the vast majority of Korean American retailers. In such a market, with a monopoly firmly in control, prices would trend toward supracompetitive levels. Which, then, would African American consumers prefer? The ethnically misaligned market where thousands of out-group producers compete against one another but shut out in-group competitors, or the ethnically aligned market dominated by one producer with clear market power?

The answer is unclear. While pertinent to the wig and extensions market, this question also underscores the ambivalence of the consumer welfare standard in antitrust; for this market is characterized by intense intra-producer competition, yet consumers are unsatisfied by their choices.

As for the more basic questions of whether Korean American firms bear market power and whether antitrust would condemn their business practices, the results are indeterminate. In the face of such indeterminacy, it would seem unwise to concoct new theories on market power or facilitating practices. However, inaction means that antitrust doctrine will have come down in

261 Thanks to Harry First for pointing this out. 
favor of one ethnic group. Such is the quandary at the heart of an ESM market where both producers and consumers are peoples of color. Err for producers, and antitrust will have endorsed a community of mostly immigrant entrepreneurs who have opted out of the mainstream U.S. economy because of racial barriers. Err for consumers, and antitrust will have upheld a racial group that has been denied participation in the sale of a product that is central to their identity.

\section{CONCLUSION}

The stakes are high for getting ESM markets right. In the U.S., interactions between peoples of color often unfold as commercial transactions in markets where groups are pushed into close quarters, hemmed in on all sides by structural racism and systemic exclusion. When, as in the wig and extensions market, those markets are ethnically misaligned, intergroup tensions can be inflamed. Such tensions exploded in 1992 with racial unrest in Los Angeles, but it was not an anomaly. Korean American-owned wig stores have been destroyed during protests in Ferguson, Missouri, in 2014 after prosecutors failed to Michael Brown's killer and also in Baltimore in 2015 after the funeral of Freddie Gray. ${ }^{262}$

As the very first step, a proper understanding of ESM markets is critical. This Article has synthesized the disparate literature on ethnically segmented markets to create the theoretical foundation for ESM markets. In using the wig and extensions market as an illustration, the Article reveals how ESM markets challenge traditional notions of market power and oligopoly stability. Hence, ESM markets and antitrust doctrine are mutually illuminating.

More empirical work must be completed before we can determine whether antitrust law conveys any recourse to African American retailers and consumers in the wig and extensions

262 Petrulis, supra note 15 , at 30. 
market. However, for the first time in decades, this market is changing quickly from new sourcing strategies that have bolstered the hand of African American competitors. The old guard of Korean American retailers is also aging out, and their children may eschew this hardscrabble business, with its intense competition, diminishing margins, and interracial tensions. Given the dynamic process of racial and ethnic formation, these children may not even feel the same fidelity toward co-ethnic bonds. Thus, by the time antitrust has devised a solution, this market may have outgrown the need for redress. 